NBER WORKING PAPER SERIES

\title{
THE FOR-PROFIT POSTSECONDARY SCHOOL SECTOR: NIMBLE CRITTERS OR AGILE PREDATORS?
}

\author{
David J. Deming \\ Claudia Goldin \\ Lawrence F. Katz \\ Working Paper 17710 \\ http://www.nber.org/papers/w17710
NATIONAL BUREAU OF ECONOMIC RESEARCH
1050 Massachusetts Avenue
Cambridge, MA 02138
December 2011

We gratefully acknowledge the superb research assistance of Tanya Avilova, Jason Poulos, and Bernie Ziprich. We are grateful to Stephanie Cellini and the Editors of the - RXLQDORIL( FRQRP IFW HUSHFWHH for helpful comments. The research reported here was supported by the Institute of Education Sciences, U.S. Department of Education, through Grant R305C110011 to Teachers College, Columbia University. The opinions expressed are those of the authors and do not represent views of the Institute, the U.S. Department of Education, or the National Bureau of Economic Research.

NBER working papers are circulated for discussion and comment purposes. They have not been peerreviewed or been subject to the review by the NBER Board of Directors that accompanies official NBER publications.

(C) 2011 by David J. Deming, Claudia Goldin, and Lawrence F. Katz. All rights reserved. Short sections of text, not to exceed two paragraphs, may be quoted without explicit permission provided that full credit, including $(\mathrm{C}$ notice, is given to the source. 
The For-Profit Postsecondary School Sector: Nimble Critters or Agile Predators?

David J. Deming, Claudia Goldin, and Lawrence F. Katz

NBER Working Paper No. 17710

December 2011

JEL No. I2,I23,J24

\begin{abstract}
Private for-profit institutions have been the fastest growing part of the U.S. higher education sector. For-profit enrollment increased from 0.2 percent to 9.1 percent of total enrollment in degree-granting schools from 1970 to 2009, and for-profit institutions account for the majority of enrollments in non-degree granting postsecondary schools. We describe the schools, students, and programs in the for-profit higher education sector, its phenomenal recent growth, and its relationship to the federal and state governments. Using the 2004 to 2009 Beginning Postsecondary Students (BPS) longitudinal survey we assess outcomes of a recent cohort of first-time undergraduates who attended for-profits relative to comparable students who attended community colleges or other public or private non-profit institutions. We find that relative to these other institutions, for-profits educate a larger fraction of minority, disadvantaged, and older students, and they have greater success at retaining students in their first year and getting them to complete short programs at the certificate and associate degree levels. But we also find that for-profit students end up with higher unemployment and "idleness" rates and lower earnings six years after entering programs than do comparable students from other schools, and that they have far greater student debt burdens and default rates on their student loans.
\end{abstract}

David J. Deming

Harvard Graduate School of Education

Gutman 411

Appian Way

Cambridge MA 02138

david_deming@gse.harvard.edu

Claudia Goldin

Department of Economics

Harvard University

Cambridge, MA 02138

and NBER

cgoldin@harvard.edu
Lawrence F. Katz

Department of Economics

Harvard University

Cambridge, MA 02138

and NBER

1katz@harvard.edu 
Private for-profit institutions have become an increasingly visible part of the U.S. higher education sector. They are today the most diverse by program and size, have been the fastest growing, have the highest fraction of nontraditional students, and obtain the greatest proportion of their total revenue from federal student aid (loan and grant) programs. They are, as well, the subjects of high-profile investigations of late and are facing major regulatory changes.

Today’s for-profit postsecondary schools were preceded a century ago by a group of proprietary schools that were also responding to an explosion in demand for technical, vocational and applied subjects. Business, managerial, and secretarial skills were in great demand in the late nineteenth and early twentieth centuries and a multitude of proprietary institutions emerged that taught accounting, management, real estate, stenography and typing. The numbers and enrollments of these institutions were greatly reduced when public high schools expanded and increased their offerings in the business and vocational areas. But many survived and morphed into some of the current for-profits, such as Blair College (established 1897; now part of Everest College), Bryant and Stratton College (1854), Gibbs College (1911), Globe University (1885), Rasmussen College (1900), and Strayer University (1892).

Distance learning, known today as on-line education, also has an interesting past in "correspondence courses" that were offered by many universities beginning in the late nineteenth century including some of the most prestigious, such as the University of Chicago and the University of Wisconsin (Watkins, 1991). On-line education is today's most rapidly growing part of higher education. Walden University, founded in 1970 and today one the largest forprofit on-line institutions, pioneered on-line studies to allow working professionals to earn further degrees.

In this article, we describe the schools, students, and programs in the for-profit higher education sector, its phenomenal recent growth, and its relationship to the federal and state governments. As a starting point, for-profit postsecondary enrollments have grown considerably during the past several decades, particularly in degree programs and at large national providers with substantial on-line offerings. Fall enrollment in for-profit degree-granting institutions grew by more than 100 -fold from 18,333 in 1970 to 1.85 million in 2009. During that same time period, total fall enrollment in all degree-granting institutions increased 2.4 fold from 8.58 million in 1970 to 20.43 million in 2009 (U.S. Department of Education, 2010, Digest, table 197). Thus, for-profit enrollment increased from 0.2 percent to 9.1 percent of total enrollment in degree-granting schools from 1970 to 2009. For-profit institutions for many decades also have accounted for the vast majority of enrollments in non-degree granting postsecondary schools (those offering shorter certificate programs) both overall and among such schools eligible for federal (Title IV) student financial aid.

Figure 1 highlights the rise of for-profits in the enrollments of Title IV eligible (degree and non-degree granting) higher education institutions since 2000, a period when enrollment in the for-profit sector tripled while enrollment for the rest of higher education increased by just 22 
percent. The solid dark line shows that the fraction of fall enrollments accounted for by the forprofits increased from 4.3 percent in 2000 to 10.7 percent in 2009. For the descriptive data presented here, we rely extensively on the Integrated Postsecondary Education Data System (IPEDS) of the U.S. Department of Education, which is an annual survey of all postsecondary institutions that participate in the federal student financial aid programs. ${ }^{1}$

Under the solid dark line in Figure 1, there is a breakdown of growth of the for-profit sector into "independent" schools, on-line institutions, and for-profit "chains." We must first define these terms since these categories are not designated in the official IPEDS data. "Independent" schools are defined here as those operating in no more than one state and having no more than five campus branches. A "chain" is a for-profit institution that operates in more than one state or has more than five campus branches within a single state. A for-profit is designated as on-line if it has the word "on-line" in its name or, more commonly, if no more than 33 percent of the school's students are from one U.S. state. All on-line institutions are considered to be chains since they serve students in multiple geographic markets. Independent schools showed little increase in their share of overall enrollments in higher-education from 2000 to 2009; chains with largely in-person enrollment showed a doubling over this period; and online institutions, typically part of national publicly-traded companies, increased from almost nothing to become the largest part of the sector. Indeed, almost 90 percent of the increase in forprofit enrollments during the last decade occurred because of the expansion of for-profit chains.

The rapid growth of the for-profits from 2000 to 2009 is illustrated in various ways in Figure 2. The for-profit share of 12-month (unduplicated headcount) enrollments increased from 5 percent in 2001 to 13 percent in 2009. The 12-month enrollment measure better captures enrollments in for-profits than the standard fall enrollment measure because it includes students in less conventional and short programs that they enter throughout the year.

For-profits have expanded their enrollment share more rapidly for women than for men and they play an increasingly large role in the higher education of older students. The for-profit enrollment share of students 25 years and older expanded from around 6 percent in 2001 to 18 percent in 2009. Undergraduate completions from for-profit institutions grew from 13 percent of the total in 2000 to almost 18 percent in 2008. The fraction of completions is considerably larger than that for enrollments because more than half of for-profit completions are certificates and most certificate programs are no more than one year.

\footnotetext{
${ }^{1}$ An on-line Appendix available with this paper at $<$ http://e-jep.org $>$ provides the details of our processing of the micro IPEDS data, linkage of the IPEDS institution-year data to financial aid to data from the National Student Loan Data System, and construction of an institution-level panel data set for 2000 to 2009.
} 
For-profit enrollments and completions in recent years have been growing most rapidly in longer degree programs. In the last decade, the for-profits increased their share of completers in all types of undergraduate programs, but more so for AAs and BAs than for certificates. They produced about 39 percent of certificates in 2000 and 42 percent in 2008. For-profit AAs were 13 percent of all AAs in 2000 but 18 percent in 2008; BAs were less than 2 percent of all in 2000 but were 5 percent of all BAs in 2008 (U.S. Department of Education, 2010, Digest, table 195).

The current incarnation of the for-profit sector is big business; its largest providers are major profitable publicly-traded corporations (Bennett, Lucchesi, and Vedder, 2010). They appear to be nimble critters that train non-traditional learners for jobs in fast growing areas, such as health care and information technology. On the other side, most of them depend on U.S. government student aid for the vast bulk of their revenues. Default rates on the loans taken out by their students vastly exceed those of other institutions of higher education and audit studies have shown that some for-profits have engaged in highly aggressive and even borderline fraudulent recruiting techniques (U.S. Government Accountability Office, 2010).

Are the for-profits nimble critters or agile predators? Using the 2004 to 2009 Beginning Postsecondary Students (BPS) longitudinal survey we assess outcomes of a recent cohort of firsttime undergraduates who attended for-profits relative to comparable students who attended community colleges or other public or private non-profit institutions. We find that relative to community colleges and other public and private non-profits, for-profits educate a larger fraction of minority, disadvantaged, and older students, and they have greater success at retaining students in their first year and getting them to complete shorter degree and non-degree programs at the certificate and AA levels. But we also find that for-profits leave students with far larger student loan debt burdens. For-profit students end up with higher unemployment and "idleness" rates and lower earnings from employment six years after entering programs than do comparable students from other schools. Not surprisingly, for-profit students have trouble paying off their student loans and have far greater default rates. And for-profit students self-report lower satisfaction with their courses of study and are less likely to consider their education and loans worth the price-tag relative to similarly-situated students who went to public and private nonprofit institutions.

\section{What is the For-Profit Postsecondary School Sector?}

\section{Apollo and the Lesser For-Profit Deities: A Diverse Sector}

The for-profit postsecondary school sector, at its simplest level, is a group of institutions that give post-high school degrees or credentials and for which some of the legal "nondistribution requirements" that potentially constrain private non-profit schools do not bind. For 
example, for-profit institutions can enter the equity market and have few constraints on the amounts they can legally pay their top managers. In practice, only the largest players in this market raise substantial capital in organized equity markets and tend to pay their top executives mega-salaries that exceed those of presidents at the public and non-profit private universities. Among the for-profits, Andrew Clark, chief executive officer of Bridgepoint Education, Inc., received more than \$20 million in 2009, while Charles Edelstein, co-chief executive officer of the Apollo Group, Inc., earned more than $\$ 11$ million. $^{2}$

For-profit sector institutions are a varied group. For-profit schools offer doctorates but also non-degree courses, and their programs run the gamut from healthcare, business, and computers to cosmetology, massage, and dog grooming. The sector contains the largest schools by enrollment in the United States and also some of the smallest. For example, the University of Phoenix Online campus enrolled over 532,000 students and Kaplan University enrolled 96,000 during the 2008-09 academic year. Taken together the largest 15 institutions account for almost 60 percent of for-profit enrollments (Bennett, Lucchesi, and Vedder 2010, table 1). But tabulations from the IPEDS also indicate that the median Title IV eligible for-profit institution had a Fall 2008 enrollment of 172 students as compared with 3,713 for the median community college (two-year public institution), 7,145 for the median four-year public university, and 1,149 for the median four-year private not-for-profit school.

The for-profit sector has become in many people's minds synonymous with the large forprofit chains that have rapidly expanded their presence in the BA and graduate education markets, especially the Apollo Group, which owns the University of Phoenix. But even though the big players in this sector do account the majority of for-profit enrollments, another important part of the sector consists of career colleges that focus on a wide range of shorter AA and certificate programs. Completions in the for-profit sector are still dominated by certificate programs and 55 percent of the certificates granted by the for-profits are awarded by the 1,700 or so independent career colleges and institutes. Our tabulations from the IPEDS indicate that certificates account for 54 percent of the degrees and awards conferred by for-profits in 2008-9.

There are several important commonalities across this mixed group. The for-profit sector offers almost no general education and liberal arts programs. For-profit programs

\footnotetext{
${ }^{2}$ Non-profits and publics are not that far behind in pay just below the very top of the for-profit scale. In 2006/07, before the stock market decline, the highest paid university president was Gordon Gee at Vanderbilt who earned slightly more than $\$ 2$ million in total compensation. A bit lower down the scale, the tenth highest paid CEO at a for-profit was Wallace Boston, Jr. CEO of American Public Education with $\$ 961 \mathrm{~K}$, while number 10 among the presidents of public institutions on the list was Jack Varsalona at Wilmington University who earned \$974K. After the stock market drop, earnings in 2008/09 for presidents at public and non-profit private universities were far lower. The data on for-profit CEO pay is from “CEO Compensation at Publicly Traded Higher-Education Companies” (2010); data on public and non-profit president’s pay is from Gibson (2009).
} 
typically are not meant to prepare students to continue to another form of higher education, as is the case with most community colleges. Rather, the for-profits almost always offer training for a vocation or trade. In that sense, they are "career colleges.” In addition, virtually all the forprofits require that admitted students have a high school diploma or another secondary school credential such as a GED. Their ability to obtain federal (Title IV) financial aid for their students is typically contingent on their admitting primarily students who have already completed secondary school. However, beyond requiring a high school degree, for-profit institutions are almost always non-selective and open admissions.

For-profit higher education is more likely to flourish in providing vocational programs that lead to certification and early job placement and have clear short-run outcomes that can serve to build institutional reputation in the labor market. But the for-profits are likely to be in a far less advantageous position where external benefits (and subsidies from donors and government) are important and the qualities of inputs and outputs are difficult to verify (Winston, 1999). For-profits also have been successful at designing programs to attract nontraditional students who may not be well served by public institutions (Breneman, Pusser, and Turner 2006).

\section{What is Title IV Eligibility?}

The for-profit sector that we analyze here includes almost exclusively those that are termed “Title IV eligible." Because for-profits often cater to independent students and those from low-income families who finance college through Pell grants and federal student loans, they have an intricate relationship with the federal government to ensure they maintain eligibility to receive Title IV federal student aid. The for-profits, like public institutions of higher education, receive an extremely large fraction of their revenues from government sources.

Title IV eligibility is granted by the U.S. Department of Education and requires that the institution be accredited by at least one of their approved accrediting agencies, be registered by one of the states, and meet other standards on a continued basis. Some of these standards concern the length of programs and some concern students and their federal loan repayment activity. A Title IV-eligible private for-profit school must either provide training for gainful employment in a recognized occupation or provide a program leading to a baccalaureate degree in the liberal arts (U.S. Department of Education 2011a). Our discussion excludes non-Title IV for-profit schools, about which little has been known because the U.S. Department of Education does not track them. Virtually all degrees are granted by Title IV eligible institutions, but programs that are less than two years in length that grant certificates (also diplomas) often are found at non-Title IV institutions. For an analysis of the importance of the non-Title IV group of for-profit schools using state registration data, see Cellini and Goldin (2011). Because virtually all degree granting institutions are Title IV eligible, the undercount from limiting the analysis to 
Title IV schools impacts only the non-degree (typically certificate) programs in institutions without any degree program.

\section{For-Profit Programs}

The for-profits loom large in the production of degrees and certificates in certain programs. For-profits produce 18 percent of all associate's degrees, but they produce 33 percent of the AAs granted in business, management and marketing, 51 percent in computer and information sciences, 23 percent in the health professions and 34 percent in security and protective services. In the public and non-profit private sectors an AA degree is often the gateway to a four-year college and, in consequence, 38 percent of these AA programs are in general studies and liberal arts programs. In the for-profits, a mere 2.4 percent are in general studies and liberal arts.

Although 5 percent of all BAs are granted by for-profit institutions, 12 percent of all BAs in business, management, and marketing are. Other large for-profit BA programs are in communications (52 percent of all BAs in communications are granted by for-profits), computer and information sciences (27 percent), and personal and culinary services (42 percent).

Certain programs are highly concentrated in the for-profit degree categories. Among AA degrees just two program groups-business, management and marketing and the health professions - account for 52 percent of all degrees. In the BA group, the business program produces almost 50 percent of the total. Among certificates granted in the Title IV for-profit sector, health professions and personal and culinary services account for 78 percent of certificate completers (U.S. Department of Education, NCES, 2009, tables 37 and 40; authors' tabulations from the IPEDS).

\section{Who Are the Students?}

The for-profit sector disproportionately serves older students, women, AfricanAmericans, Hispanics, and those with low incomes. Table 1 looks at the characteristics of students in various types of institutions of higher education. African Americans account for 13 percent of all students in higher education, but they are 22 percent of those in the for-profit sector. Hispanics are 15 percent of those in the for-profit sector, yet 11.5 percent of all students. Women are 65 percent of those in the for-profit sector. For profit students are older, about 65 percent are 25 years and older, whereas just 31 percent of those at four-year public colleges are and 40 percent of those at two-year colleges are.

Using the BPS longitudinal survey data for students entering postsecondary school during the 2003-04 academic year, we can get a more detailed picture of for-profit students relative to 
those at other colleges. Because the BPS surveys only first-time undergraduates, the results are somewhat different from the IPEDS, which surveys institutions about all students. But the storyline remains the same.

Compared with those in community colleges (almost entirely two-year public schools), for-profit students are disproportionately single parents, have much lower family incomes, and are almost twice as likely to have a General Equivalency Degree (GED). Among for-profit students in the BPS data, 55 percent are in certificate programs and just 11 percent are enrolled in a BA program. Similarly, among all for-profit students in the IPEDS, certificates are 54 percent of all completions or degrees conferred and associates are 22.5 percent (U.S. Department of Education, 2010, Digest, table 195). The BA group is just 13 percent but is the fastest growing degree group among the for-profits. Post-graduate programs, primarily master's degrees, account for the remaining 10.5 percent. ${ }^{3}$

\section{The Business Model of the For-Profit Sector}

For-profit chains led by on-line institutions experienced phenomenal growth in the past several decades. The growth has been largely due to an extension of a business model that has emphasized the special client base of the for-profits combined with the ability to "clone" successful programs using web technology and the standardization of curriculum for traditional in-person courses. In this section, we turn to the financial and business aspects of the for-profits. For more detail on the business strategies of for-profit colleges, the interested reader might start with Breneman, Pusser and Turner (2006) and Hentschke (2010).

The expansion of the chains (including on-line institutions) accounts for 87 percent of the increase in fall enrollment during the past decade. The increase in on-line enrollment alone accounts for 54 percent of the total. The rise of the chains is responsible, as well, for 80 percent of the increase in federal loan and grant volumes of the for-profits. For-profit chains and on-line programs also benefit from economies of scale in advertising and recruitment costs.

\footnotetext{
${ }^{3}$ We should note that the comparison between enrollments in the BPS and completions in the IPEDS is generally not valid when programs vary in length. But because the BPS surveys a cohort, the comparison has greater validity.
} 


\section{Client Base and Recruiting}

The Title IV eligible for-profit sector receives the majority of its revenues from federal financial aid programs in the form of loans and grants to their students. For-profits appeal to older individuals who are simultaneously employed and in school or taking care of family members. Some of the for-profits offer services, such as child care, to deter enrollees from dropping out, especially during the period when the student can get a refund and to minimize the institution's dropout rate to maintain accreditation (for example, Rosenbaum, Deil-Amien and Person, 2006). The for-profits are attractive to non-traditional students, many of whom are low income, require financial aid and need help filling out aid forms. For-profits often give generous transfer credit to students who began their BAs at other institutions.

For-profit institutions devote substantial resources to sales and marketing. Advertising in 2009, as demonstrated in one study of 13 large national chains, was around 11 percent of revenue. Sales and marketing (including advertising) for this group was around 24 percent of revenue. In consequence, the average new student recruit costs one of the large national chains about \$4,000 (Steinerman, Volshteyn and McGarrett, 2011). ${ }^{4}$ Annual tuition at for-profit institutions was about $\$ 16,000$ for a BA program, $\$ 15,000$ for an AA program, and $\$ 13,000$ for a certificate program in 2010-11, as compared to average undergraduate tuition of about $\$ 7,000$ at public four-year institutions for in-state students and \$16,000 for out-of-state students and \$22,000 for private non-profit schools (Knapp, Kelley-Reid, and Ginder, 2011, Table 3).

\section{Responsiveness to Markets}

For-profits cater to the expanding market of non-traditional students, develop curriculum and teaching practices to be able to provide identical program at multiple locations and at convenient times, and offer highly-structured programs to make timely completion feasible (Hentschke, 2010). For profits are attuned to the marketplace and are quick to open new schools, hire faculty, and add programs in growing fields and localities. For example, Turner (2006) finds that change in for-profit college enrollments are more positively correlated with changes in state college-age populations than are changes in public-sector college enrollments.

For-profits are less encumbered than public and non-profit schools by physical plant, alumni, and tenured faculty. Take the expanding health profession fields, for example. Enrollment in programs involving the health professions doubled from 2000 to 2009. In the forprofit sector it tripled, whereas in all other postsecondary institutions it increased by 1.4 times.

\footnotetext{
${ }^{4}$ The large national chains in the study are American Public Education, Apollo Group, Bridgepoint Education, Capella Education, Career Education, Corinthian Colleges, DeVry Inc., Education Management, Grand Canyon Education, ITT Educational Services, Lincoln Education, Strayer Education, and Universal Technical Institute.
} 
In consequence, the fraction of enrollment in the allied health fields in the for-profits increased from 35 percent to 52 percent, as illustrated in Figure 3. The increase in such enrollments at the national and regional chains accounts for almost the entire 17 percentage point increase.

Looking more closely at these programs, the for-profits have rapidly entered the growing fields of medical assisting, phlebotomy, x-ray and ultrasound technicians, practical nursing, and even registered nursing. The total number of AA degrees in the health professions doubled during the past decade but degrees in this area from for-profits quadrupled, with degrees from the large for-profit chains rising by a multiple of six. A similar pattern arises for certificates in the health professions, where for-profit national and regional chains more than tripled their awards from 2000 to 2009 at a time when the public sector only more than doubled theirs.

\section{On-line Education}

On-line education fits many of the features of the for-profit business model. For example, it attracts older students who need to combine work with schooling and appeals to students who do not want to learn on the academic calendar. (There is even a popular advertisement: "Earn your college degree in your pajamas.”) Much of the growth of for-profits during the last decade has been in schools emphasizing on-line programs, as seen in Figure 1.

Some of this increase was due to U.S. Department of Education regulatory changes. Prior to 1998, a Title IV-eligible institution could not have more than half of its enrollment in distance education. Then in 1998, the Higher Education Act (HEA) authorized the U.S. Department of Education to grant waivers to promote new advances in distance education. By the early 2000s many of the larger chains were granted waivers, and the limit on share of enrollment in distance education was dropped. The regulatory change in 2005 spurred the growth of dedicated on-line institutions. By 2007-08, 12 percent of undergraduates and 25 percent of graduate students at for-profits took their entire program through distance education as compared with less than 3 percent for undergraduates and 8 percent for graduate students at public and private non-profit institutions combined (U.S. Department of Education, NCES, 2011, tables A-43-1 and A-43-2).

\section{Federal Student Financial Aid}

Federal student financial aid is the lifeblood of for-profit higher education. Federal grants and loans received under Title IV of the HEA accounted for 73.7 percent of the revenues of Title IV-eligible private for-profit higher education institutions in 2008-09 (based on data in U.S. Department of Education, Federal Student Aid Data Center, 2011). Under current regulations, for-profit schools can derive no more than 90 percent of their revenue from Title IV 
financial aid sources to maintain Title IV eligibility, and the constraint comes close to binding for many for-profits. In fact, 30 percent of for-profit institutions, including many of the largest national chains such as the University of Phoenix and Kaplan University, received more than 80 percent of their revenues from federal Title IV student aid in 2008-09. These Title IV revenue figures actually understate the importance of federal student aid to for-profit institutions since they do not include military educational benefits provided to veterans and active service members, which do not count towards the limit 90 percent federal Title IV student aid revenues. The for-profits have, in consequence, actively recruited military benefit recipients—veterans, service members, and their family members - especially under the Post-9/11 GI Bill of 2008. For-profits accounted for 36.5 percent of the benefits paid under the Post-9/11 GI Bill during the first year of the program (Health, Education, Labor and Pensions Committee, 2010, p. 4).

For-profit institutions receive a disproportionate share of federal Title IV student financial aid both because they have higher tuition and fees than public institutions and because they attract large numbers of students who are financially independent or come from low-income families. For-profits accounted for 24 percent of Pell grant disbursements and 26 percent of federal student loan disbursements in 2008-09 even though they enrolled 12 percent of the students (authors' tabulations from the IPEDS and NSLDS). Half of undergraduates at for-profit schools received Pell grants, as compared with 25 percent at public and private non-profit institutions combined.

The sharp increase in the enrollments at for-profit schools has been accompanied by a rapid rise in their share of federal student financial aid from 2000 to 2010, as shown in Figure 4. The for-profit share of Pell grants increased over the last decade from 13 to 25 percent and their share of total federal student loans (both subsidized and unsubsidized loans) increased from 11 percent in 2000 to 26 percent in 2009 before dipping to 23 percent in $2010 .^{5}$

Of course, public-sector institutions receive direct taxpayer support largely from state government appropriations, enabling tuition and fees to be lower than they otherwise would be. If federal student loans to students at for-profits are repaid, taxpayer costs are actually lower to finance education in for-profits than in public-sector institutions. But the comparison is not quite apples-to-apples. The rationale for subsidies to public institutions and private non-profit schools is that they produce research with potentially large spillover benefits and that they educate students in the liberal arts and other fields that may improve civil society and generate external benefits. Also, loans to students attending for-profits often do not get repaid.

\footnotetext{
${ }^{5}$ The slight decline in the for-profit share of loans in 2010 may reflect the shift from the Federal Family Education Loan program with bank lending under federal guarantees to the Direct Loan program where the federal government makes the loans directly to students.
} 


\section{Default Rates}

Students from for-profit institutions have higher default rates on federal student loans than students in other sectors. And the default rates of for-profits have risen substantially during the last five years. ${ }^{6}$

The two-year "cohort default rate" measures the percentage of borrowers who enter repayment of federal student loans (by leaving a program through graduation or dropping out) during a fiscal year and default prior to the end of the next fiscal year. An institution loses Title IV eligibility if its two-year cohort default rate exceeds 25 percent for three consecutive years or is 40 percent in any one year. The two-year cohort default rate of for-profit institutions was 11.6 percent for fiscal year 2008 as compared with 6 percent for public institutions and 4 percent for private non-profits. The U.S. Department of Education is moving to a three-year cohort default rate standard for maintaining Title IV eligibility in fiscal year 2012. Three-year cohort default rates for fiscal year 2008 were 24.9 percent for for-profits, 7.6 percent for private non-profits, and 10.8 percent for public institutions (Steinerman, Volshteyn, and McGarrett, 2011). The sharp increase in default rates from a two- to a three-year window may, to some extent, reflect incentives for institutions to minimize defaults within the current two-year regulatory window. Thus, three-year default rates also are likely to provide a more realistic indicator of long-run loan repayment rates than the two-year default rates. ${ }^{7}$

We examine the role of student demographics, financial aid take-up, and institutional characteristics (degree types, distance education and remedial course offerings, and student services) in explaining the higher federal student loan default rates of for-profit institutions. Figure 5 graphs (regression-adjusted) differences in three-year cohort default rates by type of institution. The differences are computed from regressions of default rates on institution type (with public four-year institutions as the base group) including year dummies plus successive additions of controls for student and institution characteristics, geography, and school selectivity for pooled institution-year data covering the 2005 to 2008 fiscal years.

The raw default rates and those regression-adjusted for institutional and student characteristics are highest for the for-profit schools followed by community colleges and then four-year public and non-profit institutions. The unadjusted 11 percentage point higher three-

\footnotetext{
${ }^{6}$ Current default rates at for-profits, however, remain lower than in the late 1980s and early 1990s before the 1992 amendments to the HEA that tightened institutional eligibility for Title IV funds and removed many non-degree proprietary schools with very high default rates from the Title IV financial aid programs (Bennett, Lucchesi, and Vedder 2010).

${ }^{7}$ Furthermore, since federal Stafford loans have an initial 6 month grace period and can be up to 360 days delinquent before being considered in default, the two-year default rates typically cover a much shorter window in which a recorded default is possible.
} 
year cohort default rates for for-profits (col. 1) relative to the base group of four-year public institutions is reduced slightly to 10.5 percentage points with the addition of detailed controls for student demographics, institutional characteristics, and city fixed effects (cols. 2 and 3) despite the fact that these controls explain a substantial fraction of the cross-institution variation in default rates. The addition of the covariates modestly expands the for-profit default rate gap relative to community colleges.

The for-profit default rate is 8.7 percentage points higher than that for four-year publics and non-profits and 5.7 percentage points higher than for community colleges even when the sample is limited to non-selective (open admission) institutions (col. 4). Higher three-year cohort default rates are apparent for all segments of the for-profit sector, including independent schools, regional chains, national chains, and largely on-line institutions (see Appendix Table 1, available on-line with this paper at http://e-jep.org). National chains have higher default rates and on-line institutions lower default rates relative to all for-profits.

For-profit institutions account for a large and rising share of federal financial aid. Forprofit students have much higher default rates and account for 47 percent of defaults today. Default rates have been rising in recent years particularly for the for-profit chains and beyond what can be accounted for by basic student characteristics.

\section{Student Outcomes}

The large increase in federal student aid dollars flowing to for-profits has attracted substantial scrutiny about the quality of their programs and whether they provide students with sufficient skills to enable them to thrive in the labor market and be able to pay off their student debts (for example, Baum 2011). Simple comparisons of student outcomes between the forprofits and other institutions may be misleading: after all, the for-profits disproportionately attract minority, older, independent, and disadvantaged students. Thus, we assess student outcomes of the for-profits relative to other higher education institutions after adjusting for observable differences in students who have attended different types of schools.

The recent and rapid growth of for-profit colleges means that most of the standard individual-level longitudinal data sets do not identify those who went to for-profit institutions or do not have large enough samples of for-profit students for a meaningful analysis. To overcome these constraints we use the most recent cohort of the Beginning Postsecondary Students Longitudinal Study, known as BPS:04/09. This sample follows a sample of 2003-04 first-time beginning postsecondary students in their first, third, and sixth years since entering an undergraduate institution through 2009. Because it covers a recent cohort, a significant fraction of the sample initially enrolled in a for-profit institution. The BPS has detailed student 
background variables, low attrition rates, and an oversample of students at for-profit institutions yielding approximately 1,950 students starting at for-profits out of a total of about 16,680 students in our main sample. ${ }^{8}$

The BPS is representative of first-time postsecondary students (those starting an undergraduate program with no previous postsecondary schooling). But because a large fraction of students in for-profit institutions are older, nontraditional students returning to highereducation, they will not be picked up in this sample. Thus, our analysis estimates the for-profit school treatment effect (relative to other types of institutions) for first-time postsecondary students but not for the large group of returning students.

The outcome variables in the BPS are divided into two major groups. Those concerning college costs and financial aid are given in Table 2 and those regarding student persistence, educational attainment, employment, earnings, and satisfaction with the program are in Table 3. The raw data, given in cols. (1) to (3) of Tables 2 and 3, reveal that beginning postsecondary students at for-profits accumulate larger student debt burdens, are more likely to default on their student loans, have poorer employment outcomes five years after entering postsecondary school, and are less likely to be satisfied with their course of study than students starting at public or private non-profit schools. The short-run (one-year) dropout rate is slightly lower for starting for-profit students than those starting in a community college. For-profit students in certificate and AA programs have higher completion rates than community college students. In contrast, BA completion rates of for-profit students are much lower than of those starting in four-year public and non-profit schools.

Using the BPS, we assess whether the raw mean student outcome differences have been overstated because for-profit students differ from those in the public and the private non-profit sectors, as demonstrated in the bottom panel of Table 1. To do this, we adjust the raw outcomes for differences in baseline observables between for-profit students and others using two methods.

The first method is a standard ordinary least squares (OLS) regression of student outcomes on a rich set of covariates of student baseline characteristics at entry into college (listed in the table notes), and a dummy variable for starting postsecondary schooling in a forprofit institution. The alternative method is a matching approach, which takes students starting in for-profits as the treatment group and students starting in public and private non-profit schools

\footnotetext{
${ }^{8}$ We use the sampling weights from the BPS in all our analyses to account for the variation in sampling rates among different student subgroups. The attrition rates from the BPS:04/09 by the final 2009 survey round are relatively balanced by starting institution at 6.4 percent for students from forprofits, 10.9 percent for community college students, and 10.7 percent for students from four-year public and non-profit schools. The differences in attrition rate by starting institution type are small and not statistically significant after conditioning on baseline covariates. Unweighted sample sizes are rounded to the nearest 10 .
} 
as the control group. We compare the outcomes of the for-profit students to the control group members who are observably comparable to for-profit students. More specifically, we estimate the average treatment on treated effect of starting in a for-profit institution using nearest neighbor (propensity score) matching models with replacement excluding observations outside of common support. ${ }^{9}$ For educational attainment outcomes, the estimation samples are separated into the sub-groups of students initially enrolled in each type of program (certificate, AA, BA).

The OLS results are shown in col. (4) for the full sample and those for the matching estimator are in col. (5) of Tables 2 and 3. The OLS and matching approaches produce qualitatively and quantitatively similar estimates for almost every outcome considered

Our conclusions with regard to the relative performance of students starting in for-profit institutions are mixed. For-profit students have a higher probability of staying with a program through its first year. Early persistence translates into a higher probability of obtaining a degree or certificate in a one- or two-year program. The OLS estimates indicate that certificate seekers starting at for-profits are almost 9 percentage points more likely to gain a certificate than community college students. Although for-profit students seeking an AA are somewhat more likely than community college students to attain an AA degree, they are less likely to continue to higher-level college courses and to gain a BA degree. The matching estimates indicate that the for-profit advantage in completing certificate and AA programs is more modest and less statistically significant than the OLS estimates.

Students in for-profit institutions are also much less likely to report taking remedial courses in their first year in postsecondary school than students in other institutions. The greater ability of for-profit students to take courses they consider directly relevant and not languish in remedial courses may play a role in their greater first-year retention rates. ${ }^{10}$

For the longer undergraduate programs, such as BA, for-profits do not fare as well as four-year public and private non-profit institutions. The OLS estimate implies a 12 percentage point completion deficit and the matching model implies a 19 percentage point deficit for students starting BA programs at for-profits. The control group of students in the full range of public and private non-profit four-year schools is probably less comparable in the case of BA students than for certificate and AA programs. But even when the sample is restricted to students starting in non-selective schools, a statistically significant deficit of almost 5 percentage

\footnotetext{
${ }^{9}$ We implement the nearest-neighbor matching estimator in STATA using the routines developed by Becker and Ichino (2002).

${ }^{10}$ See Rosenbaum, Deil-Amien and Person (2006) for rich case study evidence of the roles of clearer program paths, more relevant courses, and student services in better retention and short program completion rates for students in for-profit schools relative to community colleges. Rutschow and Schneider (2011) summarize recent evidence from interventions designed to improve students' progress through remedial courses at community colleges.
} 
points remains (details in Appendix Table 2, available online with this paper at $<$ http://ejep.org>). ${ }^{11}$

Also, for-profits leave students with considerably higher debt, even conditional on a rich set of observables. For-profit students face higher sticker-price tuition and pay higher net tuition (tuition plus fees minus grants) than comparable students at other institutions. Students who began at a for-profit school default on their loans at higher rates than other students conditional on controls for demographics, academic preparation, and pre-enrollment family resources. Forprofit students have substantially higher default rates even when comparing students across school types with similar cumulative debt burdens. For example, the default rate by 2009 for the BPS:04/09 students with $\$ 5,001$ to $\$ 10,000$ in cumulative federal student loans is 26 percent for students from for-profits versus 10 percent for those from community colleges and 7 percent for those from 4-year public and nonprofit schools, and for those with $\$ 10,001$ to $\$ 20,000$ in debt the default rate among for-profit students is 16 percent versus a 3 percent rate for community college students and 2 percent rate for other 4-year college students.

Although the vast majority of students from for-profits express satisfaction with their course of study and programs, they report significantly lower satisfaction than observably similar students starting in public and non-profit schools. Students who began in for-profit colleges are also less likely to state that their education was worth the amount they paid and are less apt to think their student loans were a worthwhile investment. Even though the for-profits have higher short-run retention of students, their students are more likely to leave their certificate or degree programs before completion because of dissatisfaction with the program.

In terms of economic outcomes in the medium-run, for-profit students are more likely to be idle (that is, not working and no longer enrolled in school) six years after starting college. Among the BPS students who left school by the 2009 survey wave, those from for-profits are more likely to be unemployed and to have experienced substantial unemployment (more than three months) since leaving school. For-profit students no longer enrolled in 2009 have earnings from work in 2009 that are $\$ 1,800$ to $\$ 2,000$ lower (or 8 to 9 percent of their predicted mean earnings) than had they gone to another type of institution. ${ }^{12}$ Some of the earnings reduction is

\footnotetext{
${ }^{11}$ In addition, Appendix Tables 3 to 5 present comparable analyses for the full range of student outcomes for the sub-samples of BPS students starting certificate programs, AA programs, and BA programs respectively.

${ }^{12}$ In slight contrast, Cellini and Chaudhary (2011) find similar weekly earnings gains of around 6 percent to attending a two-year AA program at a private or public two-year college and of 15 to 17 percent (or 8 percent per year of education) to completing an AA degree at private postsecondary institutions (largely for-profit schools) and at public institutions (largely community colleges) using an individual fixed effects strategy of comparing earnings before and after college using workers under 30 years old in the 1997 National Longitudinal Survey of Youth. Cellini and Chaudhary likely understate the relative economic returns to going to a public two-year college relative to a private for-profit institution by dropping from their sample the students who continued beyond an AA to get a BA or more.
} 
due to lower rates of employment. Once we condition on employment, for-profit students have modestly lower earnings and slightly lower job satisfaction, but neither difference is statistically significant.

For-profit schools, therefore, do better in terms of first-year retention and the completion of shorter certificate and degree programs. But their first-time postsecondary students wind up with higher debt burdens, experience greater unemployment after leaving school and, if anything, have lower earnings six years after starting college than observationally-similar students from public and non-profit institutions. Not surprisingly, for-profits students end up with higher student loan default rates and are less satisfied with their college experiences.

Lower satisfaction with the programs may provide an additional psychological factor accounting for the high default rates of for-profit students, even for those with modest absolute student debt levels. In fact, students in this dataset from for-profits with less than $\$ 2,500$ in federal student loan debt had a default rate of 20 percent by 2009 as compared with 12 percent for students from community colleges and 4 percent for those from four-year public and nonprofit institutions. These patterns are troubling since the consequences of federal student loan default cannot be escaped through bankruptcy and can adversely impact an individual's credit rating and future access to credit let alone result in wage garnishment, harassment by private collection agencies, and tax refund offsets.

Although we have used the detailed background covariates in the BPS to make comparisons between individuals who are as similar as can be observed, we do not have quasiexperimental variation concerning who goes to which type of higher-education institution. Thus, one needs to be cautious in providing a causal interpretation of the estimated for-profit school treatment effects in Tables 2 and 3 since the potential problem of selection bias from nonrandom sorting on unobservables remains. Furthermore, our comparison of the medium-term outcomes for beginning postsecondary students starting at for-profits versus comparable students starting at other higher-education institutions does not directly provide information on whether attendance at a for-profit college (or, for that matter, attendance at public or private, non-profit colleges) is a worthwhile (private or social) investment.

\section{Nimble Critters or Agile Predators?}

The U.S. economy has experienced a substantial increase in the pecuniary returns to postsecondary education since 1980, particularly for BA and higher degrees (Autor, Katz, and Kearney, 2008; Goldin and Katz, 2008). At the same time, state budgetary difficulties have constrained the expansion of public-sector higher education; for example, Cellini (2009) provides compelling evidence from California on how public-sector funding constraints on 
community colleges increased the rate of entry of for-profit colleges. In the meantime, federal and state financial aid for students going to for-profit institutions has become more available and generous (for example, Cellini 2010). Based on these factors, and others discussed in this paper, the for-profit postsecondary school sector became the fastest growing part of U.S. higher education from the 1990s through 2010. Increased regulatory scrutiny and adverse publicity from Congressional hearings, investigative reporting, and GAO audits have led to a substantial slowdown in the growth of for-profit enrollments in 2011 and actual declines in new students at many of the larger national chains (Steinerman, Volshteyn, and McGarrett 2011; Fain 2011).

Evaluating the successes and failures of U.S. for-profit higher education must go beyond mean outcomes and consider the distribution of labor market effects and financial default rates. For many, the for-profits have been a success. They have played a critical role in expanding the supply of skilled workers in an era of tight state budgets and stagnating state appropriations to public sector schools. They have provided educational services to underserved populations. Their innovative use of web services has further allowed them to accommodate nontraditional students. Their disproportionate share of federal student grants and loans has enabled them to provide skills to disadvantaged populations. Short-run retention is high and the for-profits do an admirable job of graduating students from shorter certificate programs. The vast majority of their students are satisfied with their programs.

But the for-profits also charge higher tuition and fees than public-sector alternatives, and their students are more likely to end up unemployed and with substantial debts. Students who attended a for-profit have much higher default and non-repayment rates on federal student loans than do observationally similar students who attended a public or private non-profit institution.

The U.S. Department of Education (2011b) has recently sought to address this issue of the high default rate on loans to students at for-profit institutions by passing "Gainful Employment” regulations, which will require most for-profit programs and certificate programs at public and non-profit institutions to pass at least one of three metrics to remain Title IV eligible: (1) at least 35 percent of former students repaying their loans (reducing their loan by at least \$1 over the course of a year); (2) annual loan payments not exceeding 30 percent of a typical graduate’s discretionary income; or (3) annual loan payments not exceeding 12 percent of a typical graduate's earnings.

How these rules will work in practice, as students and for-profit institutions adjust to their presence, remains to be seen. The former students of for-profit institutions have comparable (but slightly lower) earnings combined with substantially higher loan burdens, relative to other school leavers, suggesting that some for-profit institutions may face challenges meeting the new Gainful Employment standards. As one example, consider the rule that the debt burden (annual federal student loan yearly payments) should not exceed 12 percent of annual earnings for a typical graduate. In fact, we find (conditional on observables) in Table 3 for the BPS that for-profit students would have had a 15 to 19 percentage point lower rate of meeting the recently enacted 
Gainful Employment earnings threshold in 2008 (four to five years after starting) than would students from other types of institutions.

In effect, the Gainful Employment rule seeks to hold the for-profits more accountable and put a greater burden on the schools, rather than only on the students who have difficulties in repaying their loans. The new regulations will also require institutions to disclose their program costs, as well as completion, placement, and loan repayment rates. These regulations will increase transparency but may be insufficient to contain an agile predator. A reality check by a third party might be needed before a student is allowed to take out a loan.

The for-profits have taken a large burden of increased enrollment in higher education off the public sector. The high default rates of their students on federal loans, however, increase their cost to the taxpayer. Regulating for-profit colleges is tricky business. The challenge is to rein in the agile predators while not stifling the innovation of these nimble critters. 


\section{References}

Autor, David H., Lawrence F. Katz and Melissa S.Kearney. 2008. “Trends in U.S. Wage Inequality: Revising the Revisionists.” Review of Economics and Statistics 90 (May), pp. 300-23.

Baum, Sandy. 2011. "Drowning in Debt: Financial Outcomes of Students in For-Profit Colleges.” Testimony to the Senate Health, Education, Labor and Pensions Committee (June 7).

Becker, Sascha O. and Andrea Ichino. 2002. "Estimation of Average Treatment Effects based on Propensity Scores.” The STATA Journal 2(4), pp. 358-77.

Bennett, Daniel L., Adam R. Lucchesi and Richard K. Vedder. 2010. "For Profit Higher Education: Growth, Innovation, and Regulation.” Center for College Affordability and Productivity, Policy Paper, (July).

Breneman, David W., Brian Pusser and Sarah E. Turner, eds. 2011. Earnings from Learning: The Rise of For-Profit Universities. Albany, NY: State University of New York Press.

Cellini, Stephanie Riegg. 2010. "Financial Aid and For-Profit Colleges: Does Aid Encourage Entry?” Journal of Policy Analysis and Management 29 (Summer), pp. 526-52.

Cellini, Stephanie Riegg. 2009. "Crowded Colleges and College Crowd-Out: The Impact of Public Subsidies on the Two-Year College Market,” American Economic Journal: Economic Policy 1 (August), pp. 1-30.

Cellini, Stephanie Riegg and Latika Chaudhary. 2011. “The Labor Market Returns to a Private Two-Year College Education.” George Washington University, working paper (April).

Cellini, Stephanie Riegg and Claudia Goldin. forthcoming. "Can For-Profit Colleges Survive without Federal Student Aid?” NBER working paper.

“CEO Compensation at Publicly Traded Higher-Education Companies.” 2010. Chronicle of Higher Education. June. 23. < at/66017/>.

Fain, Paul. 2011. "Enrollments Tumble at For-Profit Colleges.” Inside Higher Ed. November 11. < http://www.insidehighered.com/news/2011/11/11/enrollments-tumble-profit-colleges>. 
Gibson, Ellen. 2009. “College Campuses Debate Administrators' Lofty Pay,” Bloomberg Business Week, February 16.

$<$ http://www.businessweek.com/bwdaily/dnflash/content/feb2009/db20090216_614557.htm? chan=top+news_top+news+index+-+temp_news+\%2B+analysis $>$.

Goldin, Claudia and Lawrence F. Katz. 2008. The Race between Education and Technology. Cambridge, MA: The Belknap Press of Harvard University Press.

Health, Education, Labor and Pensions Committee. U.S. Senate. 2010. Benefiting Whom? ForProfit Education Companies and the Growth of Military Educational Benefits. (December 8).

Hentschke, Guilbert C. 2010. "Innovations in Business Models and Organizational Cultures: The For-Profit Sector.” USC Rossier School of Education (June).

Knapp, Laura G., Janice Kelley-Rid, and Scott A. Ginder. 2011. Postsecondary Institutions and Price of Attendance in the United States: 2010-11, First Look. U.S. Department of Education, NCES (September). http://nces.ed.gov/pubs2011/2011250.pdf

Rosenbaum, James E., Regina Deil-Amien and Ann E. Person. 2006. After Admission: From College Access to College Success. New York: Russell Sate Foundation Press.

Rutschow, Elizabeth Zachry and Emily Schneider. 2011. Unlocking the Gate: What We Know About Improving Developmental Education. New York: Manpower Demonstration Research Corporation (June).

Steinerman, Andrew, Jeffrey Volshteyn and Molly McGarrett. 2011. Education Services Data Book. J.P. Morgan, North American Equity Research, Business and Education Services (September).

Turner, Sarah E. 2006. "For-Profit Colleges in the Context of the Market for Higher Education." In D. Breneman, B. Pusser, and S. Turner, eds., Earnings from Learning: The Rise of ForProfit Universities. Albany: State University of New York Press, pp. 51-68.

U.S. Department of Education. NCES. year. Digest of Education Statistics: [year]. http://nces.ed.gov/programs/digest/

U.S. Department of Education, NCES, Integrated Postsecondary Education Data System (IPEDS). 2009. IPEDS Fall 2009 Compendium Tables. http://nces.ed.gov/das/library/tables_listings/fall2009.asp 
U.S. Department of Education. NCES. 2011. The Condition of Education 2011. http://nces.ed.gov/programs/coe/

U.S. Department of Education. 2011a. 2011-2 Federal Student Aid Handbook, Volume 2, School Eligibility and Operations. http://ifap.ed.gov/fsahandbook/1112FSAHbkVo2.html

U.S. Department of Education. 2011b. "Additional Background on the Gainful Employment Regulations.” http://www.ed.gov/news/press-releases/gainful-employment-regulations

U.S. Department of Education, Federal Student Aid Data Center. 2011. Proprietary School 90/10 Revenue Percentages, 2011 Report.

http://federalstudentaid.ed.gov/datacenter/proprietary.html

U.S. Government Accountability Office. 2010. For-Profit Colleges: Undercover Testing Finds Colleges Encouraged Fraud and Engaged in Deceptive and Questionable Marketing Practices GAO-10-948T (August 4). http://www.gao.gov/products/GAO-10-948T

Watkins, Barbara L. 1991. “A Quite Radical Idea: The Invention and Elaboration of Collegiate Correspondence Study.” In Barbara L. Watkins and Stephen J. Wright, eds., The Foundations of American Distance Education: A Century of Collegiate Correspondence Study. Dubuque, IA: Kendall/Hunt.

Winston, Gordon C. 1999. “For-Profit Higher Education: Godzilla or Chicken Little?,” Change 31 (January/February), pp. 12-19. 
Figure 1: For-Profit Institution Share of Total Title IV Fall Enrollment: Total and by School Type, 2000 to 2009

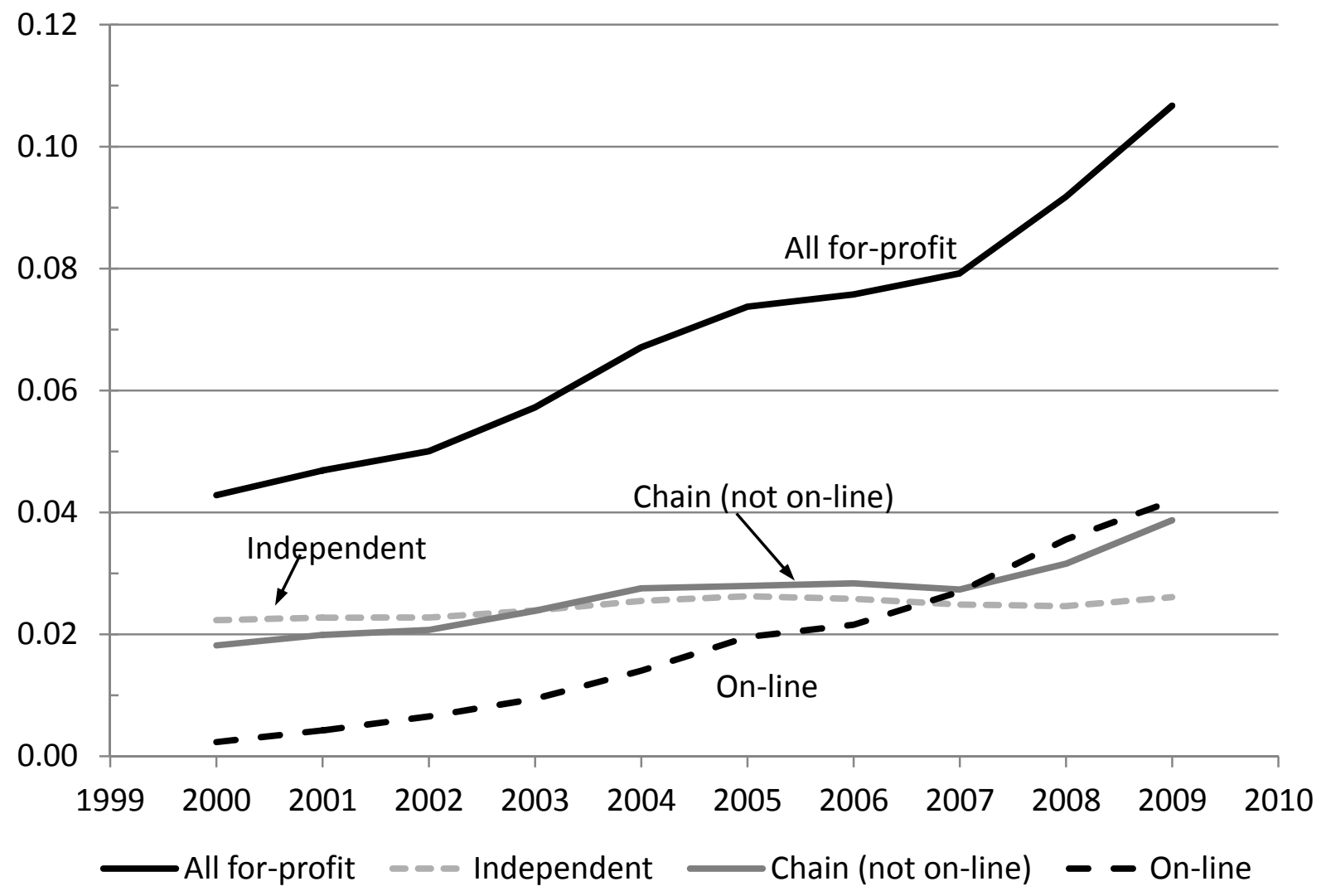

Source: IPEDS.

Notes: A for-profit institution is classified as "on-line" if it has the word on-line in its name or if not more than 33 percent of the school's students are from one U.S. state. The "chain (not-online)" category covers all other for-profit institutions that operate in more than one state or have more than five campus branches within a single state. The "independent" category includes forprofits that operate in only one state and have fewer than five campus branches. An on-line

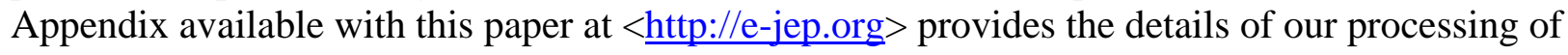
the micro IPEDS institution-level data for 2000 to 2009. 
Figure 2: For-Profit Share of Enrollments and Undergraduate Completions: 2000 to 2009

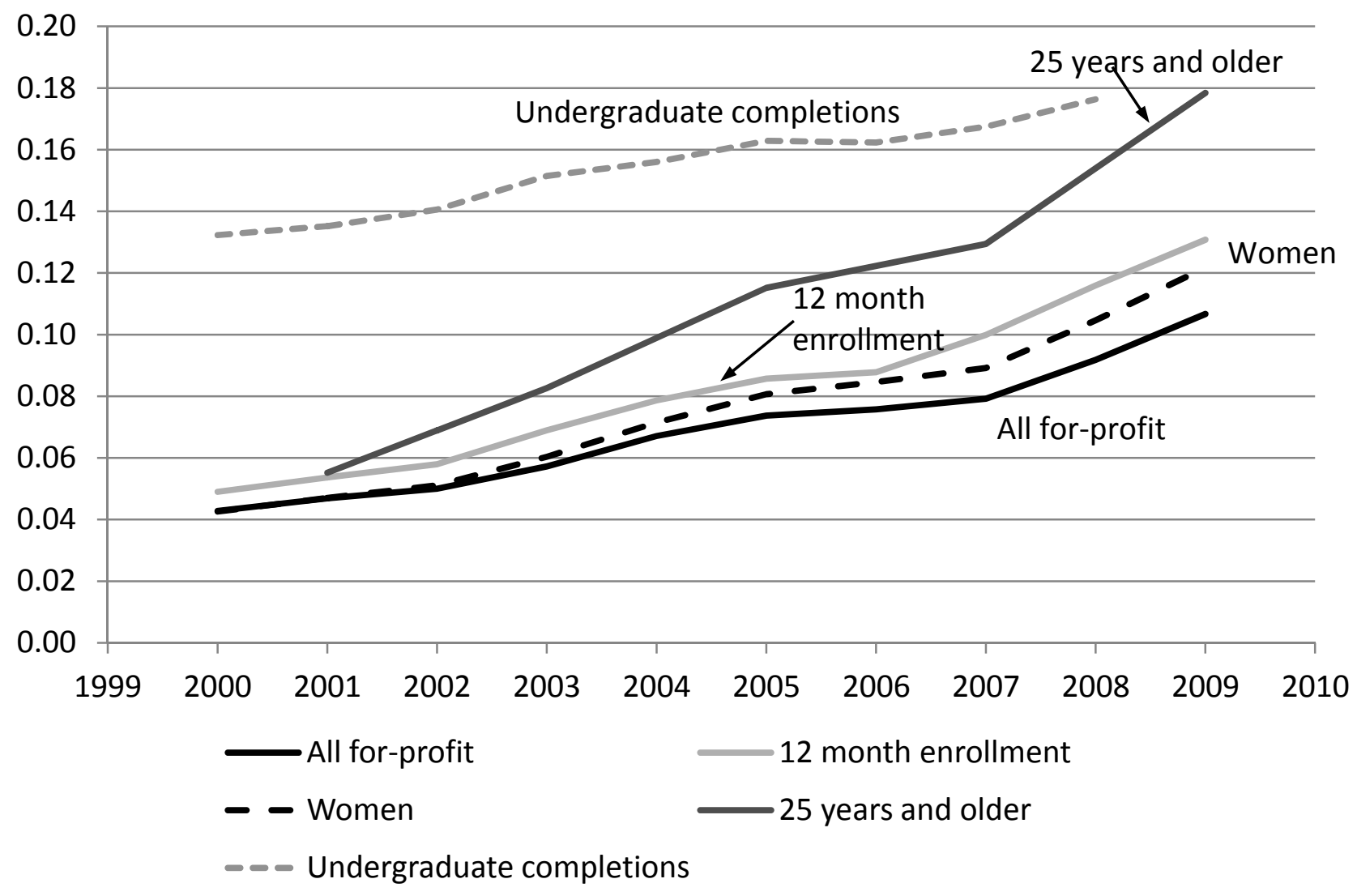

Source: IPEDS

Notes: "All for-profit" is fall enrollment, that is enrollment at the beginning of the academic year; "12 month enrollment” = unduplicated enrollment during the entire year; " 25 years and older" = fall enrollment of those 25 years and older; "women” = female fall enrollment; "undergraduate completions" = all undergraduate completions (certificates + associate's degrees + bachelor's degrees). The series for "25 years and older" is for the odd-numbered years and the even-numbered years are interpolated from those. 
Figure 3: Enrollment in Allied Health Fields by Institutional Status and Control

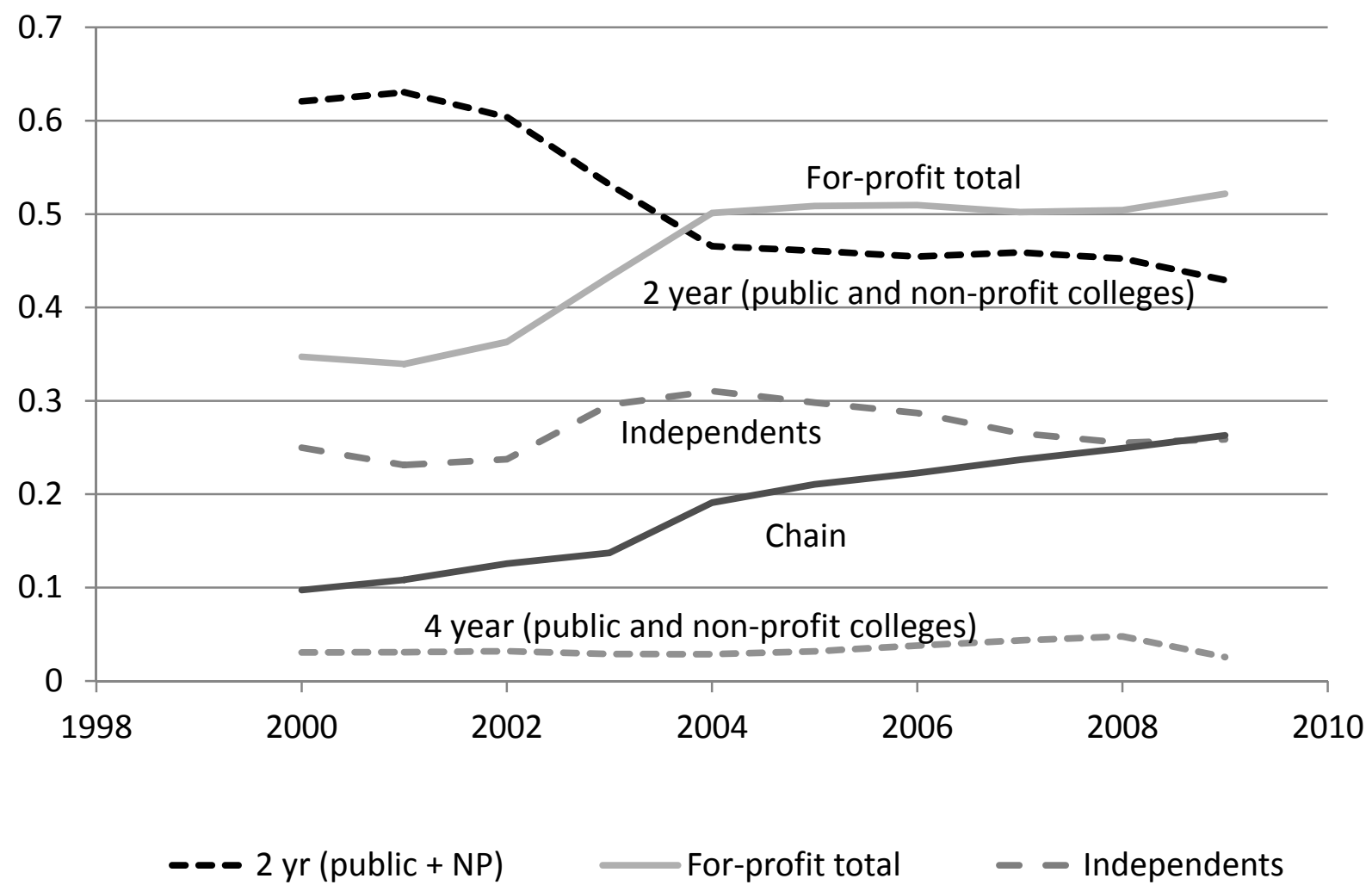

Source: IPEDS.

Notes: “4 year (public and non-profit colleges)” = public and private non-profit four-year institutions; "2 year (public and non-profit colleges)" = two year public (community colleges) and two-year private non-profit colleges; "independents” = for-profit independent (non-chain) institutions; "chain" = for-profits institutions with "on-line” in the school name or that operate in more than one state or that have more than five campus branches in a single state. 
Figure 4: For-Profit Share of Federal Financial Aid (Pell Grants and Student Loans): 2000 to 2010

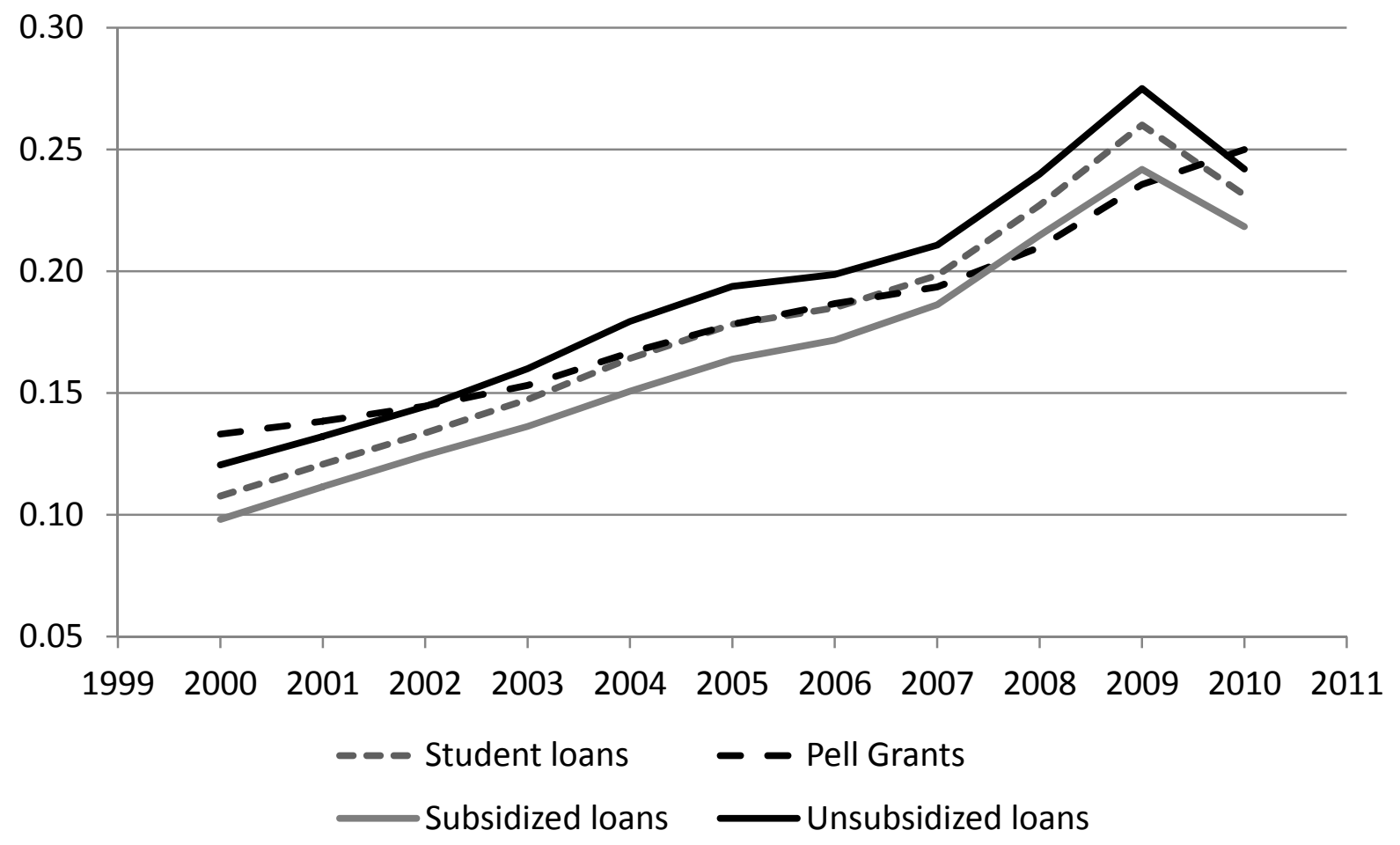

Source: National Student Loan Data System (NSLDS).

Notes: Student loans include subsidized and unsubsidized federal student loans under the Federal Family Education Loan (FFEL) and Direct Loan Programs 
Figure 5: Differences in Three-Year Cohort Default Rate by Type of Institution: 2005 to 2008 Non-profit four year $\quad$ Community college For-profit

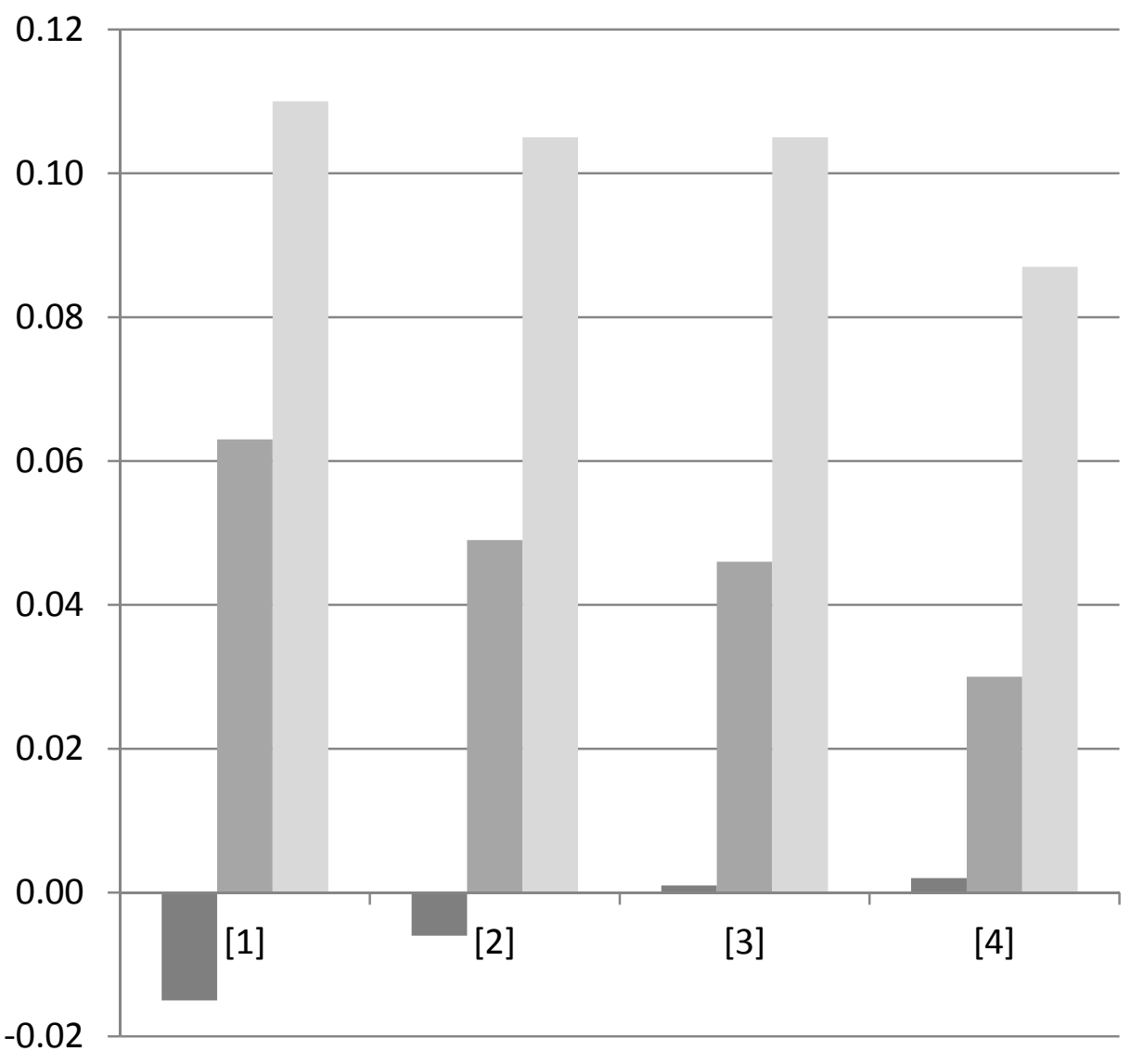

Demographic controls Financial aid controls Degree types, offerings Year fixed effects City fixed effects Limited to open admission R-squared Sample size

$\begin{array}{cccc}\text { No } & \text { Yes } & \text { Yes } & \text { Yes } \\ \text { No } & \text { Yes } & \text { Yes } & \text { Yes } \\ \text { No } & \text { Yes } & \text { Yes } & \text { Yes } \\ \text { Yes } & \text { Yes } & \text { Yes } & \text { Yes } \\ \text { No } & \text { No } & \text { Yes } & \text { Yes } \\ \text { No } & \text { No } & \text { No } & \text { Yes } \\ 0.295 & 0.428 & 0.642 & 0.553 \\ 14,655 & 14,655 & 14,655 & 9,281\end{array}$

Source: National Student Loan Data System and IPEDS.

Notes: Each bar gives the coefficient on a type of institution from a regression where the dependent variable is the three-year cohort default rate for an institution-year observation and the omitted group is four-year public institutions. The sample covers institution-year observations for the fiscal years 2005 to 2008. Demographic controls are fractions part-time, 25 years and older, female, African American, and Hispanic. Financial aid controls are the number of recipients of Pell grants and subsidized and unsubsidized federal loans, total yearly disbursement 
amounts for each, and total loans and Pell grants per enrollee. Degree types and offerings are indicators for distance education, remedial course offerings, whether the institution offers assistance with job placement, whether it offers part-time employment services for enrolled students, the highest award or degree offered by the institution, and whether it has open admissions. Standard errors are clustered by institution. Table 1 in an on-line Appendix, available with this paper at http://e-jep.org, provides the full regression, standard errors, and the effect of separating the for-profits into the subcategories of independents, regional chains, national chains, and on-line institutions. 
Table 1: Student Characteristics from the BPS and IPEDS for For-Profits, Two-Year Public Colleges, and Four-Year (Non-Profit) Colleges

\begin{tabular}{|c|c|c|c|c|}
\hline & \multicolumn{4}{|c|}{$\begin{array}{l}\text { Student Characteristics by IPEDS Institution Type, 2009/10 } \\
\end{array}$} \\
\hline & $\begin{array}{l}\text { For-Profit } \\
\text { Institutions }\end{array}$ & $\begin{array}{l}\text { Two-Year } \\
\text { Public } \\
\text { Colleges } \\
\end{array}$ & $\begin{array}{l}\text { Four-Year } \\
\text { Public } \\
\text { Colleges } \\
\end{array}$ & $\begin{array}{c}\text { Four-Year } \\
\text { Private Non- } \\
\text { Profit Colleges } \\
\end{array}$ \\
\hline Female & 0.651 & 0.570 & 0.552 & 0.576 \\
\hline African-American & 0.221 & 0.136 & 0.109 & 0.104 \\
\hline Hispanic & 0.150 & 0.157 & 0.105 & 0.093 \\
\hline Full-time & 0.579 & 0.410 & 0.733 & 0.742 \\
\hline Age 25 years and over & 0.651 & 0.404 & 0.306 & 0.392 \\
\hline Federal loans per student & 11,415 & 759 & 3,512 & 5,769 \\
\hline Pell Grant per student & 2,370 & 773 & 738 & 632 \\
\hline Tuition (in-state) & 13,103 & 2,510 & 5,096 & 24,470 \\
\hline \multirow[t]{3}{*}{ Number of institutions } & 2,995 & 1,595 & 690 & 1,589 \\
\hline & \multicolumn{4}{|c|}{ BPS 2004-2009 Sample Characteristics } \\
\hline & $\begin{array}{c}\text { For-Profit } \\
\text { Institutions }\end{array}$ & $\begin{array}{c}\text { Community } \\
\text { Colleges }\end{array}$ & $\begin{array}{r}\text { Fou } \\
\text { No }\end{array}$ & $\begin{array}{l}\text { Year Public and } \\
\text { Profit Colleges }\end{array}$ \\
\hline Female & 0.659 & 0.564 & & 0.558 \\
\hline African-American & 0.248 & 0.140 & & 0.141 \\
\hline Hispanic & 0.264 & 0.159 & & 0.103 \\
\hline Age & 24.4 & 23.8 & & 19.5 \\
\hline Single parent & 0.288 & 0.124 & & 0.030 \\
\hline Delayed enrollment after HS & 0.576 & 0.481 & & 0.142 \\
\hline HS Diploma & 0.754 & 0.852 & & 0.947 \\
\hline GED & 0.172 & 0.095 & & 0.022 \\
\hline Mother HS dropout & 0.224 & 0.137 & & 0.055 \\
\hline 2003 Family income if a dependent & 36,854 & 60,039 & & 76,509 \\
\hline 2003 Family income if independent & 17,282 & 31,742 & & 78,664 \\
\hline Enrolled full-time & 0.809 & 0.460 & & 0.903 \\
\hline Worked while enrolled, 2003-2004 & 0.635 & 0.755 & & 0.499 \\
\hline Enrolled in a certificate program & 0.551 & 0.072 & & 0.015 \\
\hline Enrolled in an AA program & 0.326 & 0.774 & & 0.061 \\
\hline Enrolled in an BA program & 0.106 & 0 & & 0.891 \\
\hline Expects to earn a BA & 0.643 & 0.799 & & 0.980 \\
\hline Sample size (unweighted) & 1,950 & 5,970 & & 8,760 \\
\hline
\end{tabular}

\section{Sources: BPS:04/09; IPEDS.}

Notes: Community colleges include two-year public and private non-profit institutions.

Unweighted sample sizes in the BPS are rounded to the nearest 10. The IPEDS tabulations cover the (undergraduate and graduate) enrollments of Title IV institutions in Fall 2009. The BPS tabulations cover beginning postsecondary students entering a Title IV institution in the 2003-04 academic year. 
Table 2: Differences in College Costs and Financial Aid between For-Profit Institutions and Other Schools for First-Time Undergraduates: 2004/2009 Beginning Postsecondary Students Longitudinal Study

\begin{tabular}{|c|c|c|c|c|c|}
\hline \multirow{7}{*}{ Dependent Variables } & \multicolumn{5}{|c|}{ Beginning Postsecondary Students (BPS, full sample) } \\
\hline & \multicolumn{3}{|c|}{ Dependent Variable Means } & \multicolumn{2}{|c|}{$\begin{array}{c}\text { For-Profit Institution } \\
\text { Impact }\end{array}$} \\
\hline & (1) & $(2)$ & (3) & $(4)$ & (5) \\
\hline & Four-Year & Two-Year & For- & OLS & Matching \\
\hline & Public and & Public and & profits & & \\
\hline & Non-profits & Non-profits & & & \\
\hline & \multicolumn{5}{|c|}{ College Costs and Financial Aid, 2003-2004 } \\
\hline \multirow[t]{2}{*}{ Applied for aid } & 0.895 & 0.749 & 0.986 & 0.094 & 0.072 \\
\hline & & & & $(0.010)$ & $(0.011)$ \\
\hline \multirow[t]{2}{*}{ Title IV loan and grant aid } & 3,837 & 1,022 & 6,852 & 4,439 & 3,417 \\
\hline & & & & $(183)$ & $(164)$ \\
\hline \multirow[t]{2}{*}{ Tuition } & 9,230 & 1,269 & 8,434 & 5,632 & 5,108 \\
\hline & & & & $(173)$ & $(201)$ \\
\hline \multirow{2}{*}{ Net tuition minus grants } & 5,183 & 734 & 5,573 & 4,521 & 4,418 \\
\hline & & & & $(157)$ & $(158)$ \\
\hline \multirow[t]{2}{*}{ Pell grant } & 0.285 & 0.294 & 0.790 & 0.190 & 0.061 \\
\hline & & & & $(0.014)$ & $(0.020)$ \\
\hline \multirow[t]{3}{*}{ Pell grant amount } & 771 & 633 & 2,149 & 557 & 180 \\
\hline & & & & $(48)$ & $(68)$ \\
\hline & \multicolumn{5}{|c|}{ Financial Aid through 2009} \\
\hline \multirow[t]{2}{*}{ Cumulative Pell grant } & 2,923 & 2,399 & 4,084 & -170 & -852 \\
\hline & & & & $(146)$ & (223) \\
\hline \multirow[t]{2}{*}{ Cumulative Title IV borrowing } & 8,702 & 3,502 & 7,699 & 3,960 & 2,239 \\
\hline & & & & $(421)$ & $(381)$ \\
\hline \multirow[t]{2}{*}{ Title IV loan balance in 2009} & 8,024 & 3,306 & 7460 & 4,071 & 2,242 \\
\hline & & & & $(460)$ & (401) \\
\hline \multirow{4}{*}{$\begin{array}{l}\text { Repaid any amount on loan, } \\
\text { conditional on a student loan } \\
\text { Defaulted on loan, } \\
\text { conditional on a student loan }\end{array}$} & 0.642 & 0.640 & 0.529 & -0.093 & -0.040 \\
\hline & & & & $(0.029)$ & $(0.046)$ \\
\hline & 0.035 & 0.056 & 0.188 & 0.067 & 0.082 \\
\hline & & & & $(0.018)$ & $(0.018)$ \\
\hline Sample Size & 8,760 & 5,970 & 1,950 & & \\
\hline
\end{tabular}

Source: BPS:04/09 Restricted-Use Data File.

Notes: The OLS column reports coefficient estimates (robust standard errors) for a for-profit institution dummy variable in regressions for each dependent variable that include the following covariates: dummy variables for race, sex, citizenship, born in the US, parents born in the US, English as the native language, household size, distance of school from home, lives with parents, marital status, single parenthood, independent student, number of kids, use of child care, maternal and paternal education categories, high school diploma, GED receipt, delayed enrollment after HS, certificate or degree program, degree expectations, region, and on or off campus residence; and second order polynomials in age, prior income 
(own for independent students and family for dependent students), household income percent of the poverty line, expected family contribution from the FAFSA, individual adjusted gross income from tax returns and government transfers. Each number in the Matching column represents the average treatment on the treated estimate (standard error) for going to a for-profit institution using from nearest neighbor (propensity score) matching with replacement and excluding observations outside of common support. The same covariates used in the OLS regressions were used for the matching models. The OLS and Matching model estimates use the BPS sampling weights. Unweighted sample sizes are rounded to the nearest 10. 
Table 3: Differences in Student Outcomes between For-Profit Institutions and Other Schools for First-Time Undergraduates: 2004/2009 Beginning Postsecondary Students Longitudinal Study

\begin{tabular}{|c|c|c|c|c|c|}
\hline \multirow{7}{*}{ Dependent Variables } & \multicolumn{5}{|c|}{ Beginning Postsecondary Students (BPS, full sample) } \\
\hline & \multicolumn{3}{|c|}{ Dependent Variable Means } & \multicolumn{2}{|c|}{$\begin{array}{c}\text { For-Profit Institution } \\
\text { Impact }\end{array}$} \\
\hline & (1) & (2) & (3) & (4) & (5) \\
\hline & Four-Year & Two-Year & For- & OLS & Matching \\
\hline & Public and & Public and & profits & & \\
\hline & Non-profits & Non-profits & & & \\
\hline & \multicolumn{5}{|c|}{ Persistence and Educational Attainment } \\
\hline Left school in 2003-2004 & 0.062 & 0.233 & 0.212 & $\begin{array}{l}-0.046 \\
(0.016)\end{array}$ & $\begin{array}{l}-0.051 \\
(0.018)\end{array}$ \\
\hline \multirow{4}{*}{$\begin{array}{l}\text { Attained certificate } \\
\text { (enrolled in certificate program) } \\
\text { Attained AA } \\
\text { (enrolled in AA program) }\end{array}$} & \multirow[t]{4}{*}{-} & \multirow[t]{2}{*}{0.424} & \multirow[t]{2}{*}{0.537} & 0.086 & 0.046 \\
\hline & & & & $(0.036)$ & $(0.034)$ \\
\hline & & \multirow[t]{2}{*}{0.224} & \multirow[t]{2}{*}{0.284} & 0.041 & 0.019 \\
\hline & & & & $(0.028)$ & $(0.029)$ \\
\hline \multirow{2}{*}{$\begin{array}{l}\text { Attained AA or more } \\
\text { (enrolled in AA program) }\end{array}$} & \multirow[t]{2}{*}{-} & \multirow[t]{2}{*}{0.283} & \multirow[t]{2}{*}{0.291} & -0.006 & -0.016 \\
\hline & & & & $(0.028)$ & $(0.030)$ \\
\hline \multirow{6}{*}{$\begin{array}{l}\text { Attained BA } \\
\text { (enrolled in BA program) } \\
\text { Idle (not employed, not enrolled) } \\
\text { at } 2009 \text { survey } \\
\text { Enrolled in } 2009\end{array}$} & \multirow[t]{2}{*}{0.658} & \multirow[t]{2}{*}{-} & \multirow[t]{2}{*}{0.262} & -0.115 & -0.194 \\
\hline & & & & $(0.045)$ & $(0.052)$ \\
\hline & \multirow[t]{2}{*}{0.106} & \multirow[t]{2}{*}{0.133} & 0.236 & 0.052 & 0.058 \\
\hline & & & & $(0.017)$ & $(0.017)$ \\
\hline & 0.271 & 0.389 & 0.216 & -0.114 & -0.080 \\
\hline & & & & $(0.018)$ & $(0.019)$ \\
\hline & Employm & nt and Earnin & for those & nger enrc & in 2009) \\
\hline Any job in 2009 & 0.839 & 0.784 & 0.706 & -0.028 & -0.031 \\
\hline & & & & $(0.021)$ & $(0.022)$ \\
\hline Earnings from work in 2009 & 28,613 & 24,795 & 19,950 & $-1,771$ & $-1,936$ \\
\hline & & & & $(931)$ & $(950)$ \\
\hline Earnings from work in 2009, & 34,080 & 31,622 & 28,243 & $-1,355$ & -243 \\
\hline conditional on employment & & & & $(934)$ & (937) \\
\hline Unemployed and seeking work & 0.121 & 0.148 & 0.232 & 0.048 & 0.067 \\
\hline & & & & $(0.019)$ & $(0.020)$ \\
\hline Unemployed 3 months or more & 0.238 & 0.259 & 0.404 & 0.077 & 0.084 \\
\hline after leaving school & & & & $(0.022)$ & $(0.023)$ \\
\hline Earnings less than & 0.135 & 0.046 & 0.271 & 0.194 & 0.147 \\
\hline gainful employment standard & & & & $(0.019)$ & $(0.017)$ \\
\hline & & urse Content & Job and & ol Satisfa & \\
\hline Remedial coursework in 2003-4 & 0.181 & 0.289 & 0.076 & -0.180 & -0.187 \\
\hline & & & & $(0.015)$ & $(0.017)$ \\
\hline Left school because dissatisfied & 0.012 & 0.024 & 0.081 & 0.043 & 0.048 \\
\hline$(2003-2004)$ & & & & $(0.009)$ & $(0.009)$ \\
\hline Left school because dissatisfied & 0.032 & 0.051 & 0.117 & 0.052 & 0.053 \\
\hline$(2003-2006)$ & & & & $(0.013)$ & $(0.011)$ \\
\hline Education was worth the cost & 0.802 & 0.821 & 0.648 & -0.204 & -0.179 \\
\hline & & & & $(0.019)$ & $(0.017)$ \\
\hline
\end{tabular}




\begin{tabular}{lccccc}
\hline $\begin{array}{l}\text { Loans were a worthwhile } \\
\text { investment }\end{array}$ & 0.836 & 0.803 & 0.664 & -0.143 & -0.121 \\
$\begin{array}{l}\text { Satisfied with major or program } \\
\text { Satisfied with current job, }\end{array}$ & 0.860 & 0.871 & 0.789 & $\begin{array}{c}(0.022) \\
-0.097\end{array}$ & $\begin{array}{l}(0.024) \\
-0.065\end{array}$ \\
$\begin{array}{l}\text { (employed, not enrolled) } \\
\text { Sample Size }\end{array}$ & 0.772 & 0.764 & 0.752 & $-0.017)$ & $\begin{array}{c}(0.015) \\
-0.032\end{array}$ \\
\hline \hline
\end{tabular}

Source and Notes: See Table 2. 
Appendix

IPEDS and student financial aid

We have constructed a consistent institution-year panel data set using the 2000 to 2009 micro data from the Integrated Postsecondary Education Data System (IPEDS) collected and maintained by the National Center for Education Statistics of the U.S. Department of Education. We use the IPEDS data on enrollments (fall, 12 month, and full-time equivalent), degrees and awards, tuition, revenues and expenditures, and other institutional characteristics. The IPEDS data are available from and documented at http://nces.ed.gov/ipeds/.

We match the IPEDS data to institution-level data on Pell grants, student loans volumes and cohort default rates from the National Student Loan Data System (NSLDS). For the financial data, see: http://federalstudentaid.ed.gov/datacenter/index.html.

Student loan volumes by institution come from the Direct Loan program (where the federal government gives loans directly to students) and the Federal Family Education Loan (FFEL) Program, and includes both subsidized (where the government pays interest while students are still enrolled in school) and unsubsidized loan programs. Under FFELP, private lenders provided capital for loans that were subsidized and guaranteed against default by the federal government. The FFEL program was terminated in 2009.

Institutions in IPEDS are assigned a unique "unitid" that is constant across years. Unitids are assigned to physical branches of an institution, and a single school will have one unitid for each branch. However, each school is also assigned an Office of Postsecondary Education ID (known as "opeid”) that is constant across branches. The NSLDS data are linked to the opeid and are not broken out separately by branch. For example, IPEDS has enrollment and degree information separated by campus branch (i.e., by unitid), but information from NSLDS on student loan and Pell grant volumes is only available for the overall institution (i.e., the opeid).

\section{Match rate between IPEDS and NSLDS}

We are able to match about 94 percent of the unitids in IPEDS to an opeid from NSLDS. Around 67 percent of the schools are classified in IPEDS as for-profit institutions. The unmatched 6 percent of schools (722 of 11,889) contain 1.4 percent of total enrollment in 2009 and less in earlier years.

We were unable to match about 5.6 percent of the opeids in NSLDS to any IPEDS unitid. About 61 percent (405 of 661) of those institutions were classified by NSLDS as "proprietary" schools, or for-profits. Schools without unitids are about 1 percent of subsidized and unsubsidized loan volumes in 2009 and about 2.4 percent of Pell Grants. Among proprietary schools, those that were not successfully matched to IPEDS represent less than 1 percent of loans and about 1 percent of Pell grants. 
Appendix Table 1: Regression of Three-Year Cohort Default Rate on Type of Institution: 2005 to 2008

\begin{tabular}{|c|c|c|c|c|c|c|c|c|c|c|}
\hline & (1) & $(2)$ & (3) & (4) & (5) & (6) & (7) & (8) & (9) & (10) \\
\hline Non-profit four year & $\begin{array}{c}-0.015 \\
(0.003)\end{array}$ & $\begin{array}{c}-0.006 \\
(0.003)\end{array}$ & $\begin{array}{c}0.001 \\
(0.004)\end{array}$ & $\begin{array}{c}0.002 \\
(0.011)\end{array}$ & $\begin{array}{c}0.000 \\
(0.003)\end{array}$ & $\begin{array}{c}-0.015 \\
(0.003)\end{array}$ & $\begin{array}{c}-0.007 \\
(0.003)\end{array}$ & $\begin{array}{c}-0.001 \\
(0.004)\end{array}$ & $\begin{array}{c}0.001 \\
(0.010)\end{array}$ & $\begin{array}{c}-0.001 \\
(0.004)\end{array}$ \\
\hline Community college & $\begin{array}{c}0.063 \\
(0.003)\end{array}$ & $\begin{array}{c}0.049 \\
(0.004)\end{array}$ & $\begin{array}{c}0.046 \\
(0.005)\end{array}$ & $\begin{array}{c}0.030 \\
(0.009)\end{array}$ & $\begin{array}{c}0.046 \\
(0.004)\end{array}$ & $\begin{array}{c}0.063 \\
(0.003)\end{array}$ & $\begin{array}{c}0.047 \\
(0.004)\end{array}$ & $\begin{array}{c}0.045 \\
(0.005)\end{array}$ & $\begin{array}{c}0.030 \\
(0.009)\end{array}$ & $\begin{array}{c}0.044 \\
(0.005)\end{array}$ \\
\hline For-profit & $\begin{array}{c}0.110 \\
(0.003)\end{array}$ & $\begin{array}{c}0.105 \\
(0.004)\end{array}$ & $\begin{array}{c}0.105 \\
(0.005)\end{array}$ & $\begin{array}{c}0.087 \\
(0.009)\end{array}$ & $\begin{array}{c}0.105 \\
(0.004)\end{array}$ & & & & & \\
\hline For-profit $\times 2008$ & & & & & $\begin{array}{c}0.005 \\
(0.007)\end{array}$ & & & & & \\
\hline Independents & & & & & & $\begin{array}{c}0.102 \\
(0.003)\end{array}$ & $\begin{array}{c}0.096 \\
(0.005)\end{array}$ & $\begin{array}{c}0.098 \\
(0.005)\end{array}$ & $\begin{array}{c}0.080 \\
(0.010)\end{array}$ & $\begin{array}{c}0.098 \\
(0.005)\end{array}$ \\
\hline Independents $\times 2008$ & & & & & & & & & & $\begin{array}{c}-0.013 \\
(0.010)\end{array}$ \\
\hline Regional chain & & & & & & $\begin{array}{c}0.123 \\
(0.006)\end{array}$ & $\begin{array}{c}0.113 \\
(0.007)\end{array}$ & $\begin{array}{c}0.111 \\
(0.007)\end{array}$ & $\begin{array}{c}0.091 \\
(0.011)\end{array}$ & $\begin{array}{c}0.110 \\
(0.007)\end{array}$ \\
\hline Regional chain $\times 2008$ & & & & & & & & & & $\begin{array}{c}0.011 \\
(0.015)\end{array}$ \\
\hline National chain & & & & & & $\begin{array}{c}0.152 \\
(0.006)\end{array}$ & $\begin{array}{c}0.131 \\
(0.006)\end{array}$ & $\begin{array}{c}0.127 \\
(0.006)\end{array}$ & $\begin{array}{c}0.108 \\
(0.010)\end{array}$ & $\begin{array}{c}0.124 \\
(0.006)\end{array}$ \\
\hline National chain $\times 2008$ & & & & & & & & & & $\begin{array}{c}0.032 \\
(0.008)\end{array}$ \\
\hline On-line & & & & & & $\begin{array}{c}0.079 \\
(0.016)\end{array}$ & $\begin{array}{c}0.076 \\
(0.014)\end{array}$ & $\begin{array}{c}0.089 \\
(0.017)\end{array}$ & $\begin{array}{c}0.075 \\
(0.019)\end{array}$ & $\begin{array}{c}0.081 \\
(0.017)\end{array}$ \\
\hline On-line $\times 2008$ & & & & & & & & & & $\begin{array}{c}0.059 \\
(0.020)\end{array}$ \\
\hline R-squared & 0.295 & 0.428 & 0.642 & 0.553 & 0.642 & 0.305 & 0.433 & 0.644 & 0.555 & 0.645 \\
\hline Sample Size & 14,655 & 14,655 & 14,655 & 9,281 & 14,655 & 14,655 & 14,655 & 14,655 & 9,281 & 14,655 \\
\hline Demographic controls & No & Yes & Yes & Yes & Yes & No & Yes & Yes & Yes & Yes \\
\hline Financial aid controls & No & Yes & Yes & Yes & Yes & No & Yes & Yes & Yes & Yes \\
\hline Degree types, offerings & No & Yes & Yes & Yes & Yes & No & Yes & Yes & Yes & Yes \\
\hline Year fixed effects & Yes & Yes & Yes & Yes & Yes & Yes & Yes & Yes & Yes & Yes \\
\hline City fixed effects & No & No & Yes & Yes & Yes & No & No & Yes & Yes & Yes \\
\hline Limit to open admission & No & No & No & Yes & No & No & No & No & Yes & No \\
\hline
\end{tabular}


Source: National Student Loan Data System and IPEDS.

Notes: The dependent variable is the three-year cohort default rate for an institution-year observation. The sample covers institutionyear observations for the fiscal years 2005 to 2008. "Independents" are for-profit schools that operate in only one state and have no more than five branches. A "regional chain" is a for-profit institution that operates in more than one state, or has more than five campus branches within a single state, but operates in no more than two census divisions. A "national chain" is a for-profit institution that operates in at least three separate census divisions. A for-profit institution is "online” if it either has the word "online” in the school's name, or if no more than 33 percent of its students come from any single U.S. state. Demographic controls are fractions parttime, 25 years and over, female, African American, and Hispanic. Financial aid controls are the number of recipients of Pell grants and subsidized and unsubsidized federal loans, total yearly disbursement amounts for each, and total loans and Pell grants per enrollee. Degree types and offerings are indicators for distance education, remedial course offerings, whether the institution offers assistance with job placement, whether it offers part-time employment services for enrolled students, the highest award or degree offered by the institution, and whether it has open admissions. Standard errors are clustered by institution and are in parentheses. Omitted category is four-year public. 
Appendix Table 2: For-Profit Institution Impact on Student Outcomes for First-Time Undergraduates at Non-Selective Institutions: BPS:04/09

\begin{tabular}{|c|c|c|c|c|c|}
\hline \multirow[b]{3}{*}{ Dependent Variables } & \multicolumn{5}{|c|}{ 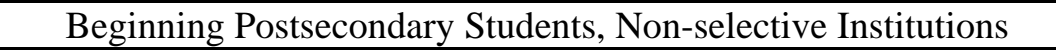 } \\
\hline & \multicolumn{3}{|c|}{ Dependent Variable Means } & \multicolumn{2}{|c|}{$\begin{array}{c}\text { For-Profit Institution } \\
\text { Impact }\end{array}$} \\
\hline & $\begin{array}{c}(1) \\
\text { Four-Year } \\
\text { Public and } \\
\text { Non-profits }\end{array}$ & $\begin{array}{c}\text { (2) } \\
\text { Two-Year } \\
\text { Public and } \\
\text { Non-profits }\end{array}$ & $\begin{array}{c}\text { (3) } \\
\text { For- profits }\end{array}$ & $\begin{array}{l}(4) \\
\text { OLS }\end{array}$ & $\begin{array}{c}\text { (5) } \\
\text { Matching }\end{array}$ \\
\hline & \multicolumn{5}{|c|}{ Financial Aid, 2003-2004 } \\
\hline Applied for Aid & 0.905 & 0.749 & 0.986 & $\begin{array}{c}0.092 \\
(0.010)\end{array}$ & $\begin{array}{c}0.056 \\
(0.011)\end{array}$ \\
\hline Title IV loan and grant aid & 3,989 & 1,022 & 6,852 & $\begin{array}{l}4,628 \\
(179)\end{array}$ & $\begin{array}{l}3,567 \\
(156)\end{array}$ \\
\hline Tuition & 6,737 & 1,269 & 8,434 & $\begin{array}{l}5,979 \\
(160)\end{array}$ & $\begin{array}{l}5,243 \\
(176)\end{array}$ \\
\hline Net tuition minus grants & 3,457 & 734 & 5,573 & $\begin{array}{l}4,660 \\
(148)\end{array}$ & $\begin{array}{l}4,351 \\
(143)\end{array}$ \\
\hline Pell grant & 0.407 & 0.294 & 0.790 & $\begin{array}{c}0.190 \\
(0.014)\end{array}$ & $\begin{array}{c}0.053 \\
(0.021)\end{array}$ \\
\hline \multirow[t]{2}{*}{ Pell grant amount } & 1,092 & 633 & 2,149 & $\begin{array}{l}570 \\
(49)\end{array}$ & $\begin{array}{l}195 \\
(68)\end{array}$ \\
\hline & \multicolumn{5}{|c|}{ Financial Aid through 2009} \\
\hline Cumulative Pell grant & 3,545 & 2,399 & 4,084 & $\begin{array}{c}100 \\
(145)\end{array}$ & $\begin{array}{l}-657 \\
(212)\end{array}$ \\
\hline Cumulative Title IV borrowing & 8,489 & 3,502 & 7,699 & $\begin{array}{l}4,562 \\
(417)\end{array}$ & $\begin{array}{l}2,781 \\
(354)\end{array}$ \\
\hline Title IV loan balance, 2009 & 8,153 & 3,306 & 7,460 & $\begin{array}{l}4,640 \\
(449)\end{array}$ & $\begin{array}{l}2,759 \\
(371)\end{array}$ \\
\hline $\begin{array}{l}\text { Repaid any amount on loan, } \\
\text { conditional on a student loan }\end{array}$ & 0.588 & 0.640 & 0.529 & $\begin{array}{l}-0.098 \\
(0.030)\end{array}$ & $\begin{array}{l}-0.033 \\
(0.044)\end{array}$ \\
\hline $\begin{array}{l}\text { Defaulted on loan, } \\
\text { conditional on a student loan }\end{array}$ & 0.073 & 0.056 & 0.188 & $\begin{array}{c}0.058 \\
(0.018)\end{array}$ & $\begin{array}{c}0.078 \\
(0.019)\end{array}$ \\
\hline Left school in 2003-2004 & 0.134 & $\begin{array}{c}\text { Persistence a } \\
0.233\end{array}$ & $\begin{array}{l}\text { Id Educationa } \\
0.212\end{array}$ & $\begin{array}{c}\text { Attainme } \\
-0.053 \\
(0.016)\end{array}$ & $\begin{array}{l}-0.054 \\
(0.018)\end{array}$ \\
\hline Attained certificate & 0.031 & 0.112 & 0.316 & $\begin{array}{c}0.038 \\
(0.014)\end{array}$ & $\begin{array}{l}0.043 \\
(0.19)\end{array}$ \\
\hline Attained AA & 0.071 & 0.177 & 0.112 & $\begin{array}{l}-0.043 \\
(0.015)\end{array}$ & $\begin{array}{l}-0.021 \\
(0.015)\end{array}$ \\
\hline Attained BA & 0.532 & 0.110 & 0.040 & $\begin{array}{l}-0.049 \\
(0.011)\end{array}$ & $\begin{array}{l}-0.044 \\
(0.012)\end{array}$ \\
\hline Still enrolled in 2009 & 0.336 & 0.389 & 0.216 & $\begin{array}{l}-0.118 \\
(0.018)\end{array}$ & $\begin{array}{l}-0.098 \\
(0.020)\end{array}$ \\
\hline Idle (not employed, not enrolled) & 0.132 & 0.133 & 0.236 & $\begin{array}{c}0.046 \\
(0.017)\end{array}$ & $\begin{array}{c}0.056 \\
(0.017)\end{array}$ \\
\hline Left survey & 0.113 & 0.109 & 0.064 & $\begin{array}{l}-0.024 \\
(0.011)\end{array}$ & $\begin{array}{l}-0.020 \\
(0.012)\end{array}$ \\
\hline
\end{tabular}




\begin{tabular}{|c|c|c|c|c|c|}
\hline Any job in 2009 & 0.790 & 0.784 & 0.706 & $\begin{array}{l}-0.020 \\
(0.021)\end{array}$ & $\begin{array}{l}-0.093 \\
(0.021)\end{array}$ \\
\hline Earnings from work in 2009 & 24,626 & 24,795 & 19,950 & $\begin{array}{l}-1237 \\
(967)\end{array}$ & $\begin{array}{l}-4168 \\
(970)\end{array}$ \\
\hline $\begin{array}{l}\text { Earnings from work in 2009, } \\
\text { conditional on employment }\end{array}$ & 31,188 & 31,622 & 28,243 & $\begin{array}{l}-885 \\
(969)\end{array}$ & $\begin{array}{c}234 \\
(902)\end{array}$ \\
\hline Unemployed and seeking work & 0.164 & 0.148 & 0.232 & $\begin{array}{c}0.041 \\
(0.019)\end{array}$ & $\begin{array}{c}0.062 \\
(0.021)\end{array}$ \\
\hline $\begin{array}{l}\text { Unemployed more than } 3 \text { months } \\
\text { since leaving school }\end{array}$ & 0.277 & 0.259 & 0.404 & $\begin{array}{c}0.078 \\
(0.022)\end{array}$ & $\begin{array}{c}0.085 \\
(0.024)\end{array}$ \\
\hline $\begin{array}{l}\text { Earnings do not meet the } \\
\text { Gainful Employment standard }\end{array}$ & 0.156 & 0.046 & 0.271 & $\begin{array}{c}0.204 \\
(0.019)\end{array}$ & $\begin{array}{c}0.152 \\
(0.017)\end{array}$ \\
\hline Remedial coursework & 0.235 & $\begin{array}{c}\text { faction } n \\
0.289\end{array}$ & $\begin{array}{c}\text { ogram, } \\
0.076\end{array}$ & $\begin{array}{l}\text { l, Loans, } \\
-0.196 \\
(0.015)\end{array}$ & $\begin{array}{l}-0.198 \\
(0.017)\end{array}$ \\
\hline $\begin{array}{l}\text { Left school because dissatisfied, } \\
\text { 2003-2004 }\end{array}$ & 0.036 & 0.024 & 0.081 & $\begin{array}{c}0.038 \\
(0.009)\end{array}$ & $\begin{array}{c}0.039 \\
(0.009)\end{array}$ \\
\hline $\begin{array}{l}\text { Left school because dissatisfied, } \\
\text { 2003-2006 }\end{array}$ & 0.073 & 0.051 & 0.117 & $\begin{array}{c}0.046 \\
(0.013)\end{array}$ & $\begin{array}{r}0.048 \\
(0.011)\end{array}$ \\
\hline Education was worth the cost & 0.771 & 0.821 & 0.648 & $\begin{array}{l}-0.204 \\
(0.019)\end{array}$ & $\begin{array}{l}-0.179 \\
(0.018)\end{array}$ \\
\hline $\begin{array}{l}\text { Loans were a worthwhile } \\
\text { Investment }\end{array}$ & 0.804 & 0.803 & 0.664 & $\begin{array}{l}-0.142 \\
(0.023)\end{array}$ & $\begin{array}{l}-0.118 \\
(0.024)\end{array}$ \\
\hline $\begin{array}{l}\text { Satisfied with major } \\
\text { or course of study }\end{array}$ & 0.846 & 0.871 & 0.789 & $\begin{array}{l}-0.101 \\
(0.017)\end{array}$ & $\begin{array}{l}-0.070 \\
(0.015)\end{array}$ \\
\hline $\begin{array}{l}\text { Satisfied with current job } \\
\text { (employed, not enrolled) }\end{array}$ & 0.772 & 0.764 & 0.752 & $\begin{array}{l}-0.014 \\
(0.026)\end{array}$ & $\begin{array}{l}-0.011 \\
(0.024)\end{array}$ \\
\hline Sample size & 1,920 & 5,930 & 1,950 & & \\
\hline
\end{tabular}

Source: BPS:04/09 Restricted-Use Data File.

Notes: The regression samples exclude students who started at selective four-year institutions. The OLS column reports coefficient estimates (robust standard errors) for a for-profit institution dummy variable in regressions for each dependent variable that include the same additional covariates as those listed in the notes to Table 3. Each number in the Matching column represents the average treatment on the treated estimate (standard error) for going to a for-profit institution using from nearest neighbor (propensity score) matching with replacement and excluding observations outside of common support. The same covariates used in the OLS regressions were used for the matching models. The OLS and Matching model estimates use the BPS sampling weights. Unweighted sample sizes are rounded to the nearest 10. 
Appendix Table 3: For-Profit Institution Impact on Student Outcomes for First-Time Undergraduates in Certificate Programs: BPS:04/09

\begin{tabular}{|c|c|c|c|c|c|}
\hline \multirow[b]{3}{*}{ Dependent Variables } & \multicolumn{5}{|c|}{ Beginning Postsecondary Students, Certificate Program Enrollees } \\
\hline & \multicolumn{3}{|c|}{ Dependent Variable Means } & \multicolumn{2}{|c|}{$\begin{array}{c}\text { For-Profit Institution } \\
\text { Impact }\end{array}$} \\
\hline & $\begin{array}{c}1) \\
\text { Four-Year } \\
\text { Public and } \\
\text { Non-profits }\end{array}$ & $\begin{array}{c}(2) \\
\text { Two-Year } \\
\text { Public and } \\
\text { Non-profits }\end{array}$ & $\begin{array}{c}\text { (3) } \\
\text { For- profits }\end{array}$ & $\begin{array}{l}(4) \\
\text { OLS }\end{array}$ & $\begin{array}{c}\text { (5) } \\
\text { Matching }\end{array}$ \\
\hline & \multicolumn{5}{|c|}{ Financial Aid, 2003-2004 } \\
\hline Applied for Aid & 0.883 & 0.836 & 0.991 & $\begin{array}{c}0.069 \\
(0.014)\end{array}$ & $\begin{array}{c}0.068 \\
(0.020)\end{array}$ \\
\hline Title IV loan and grant aid & 3,693 & 1,362 & 6,285 & $\begin{array}{l}3,353 \\
(252)\end{array}$ & $\begin{array}{l}3,005 \\
(238)\end{array}$ \\
\hline Tuition & 7,171 & 1,425 & 8,129 & $\begin{array}{l}5243 \\
(176)\end{array}$ & $\begin{array}{l}4979 \\
(276)\end{array}$ \\
\hline Net tuition minus grants & 4,227 & 757 & 5,212 & $\begin{array}{l}4,023 \\
(242)\end{array}$ & $\begin{array}{l}3,911 \\
(242)\end{array}$ \\
\hline Pell grant & 0.465 & 0.409 & 0.888 & $\begin{array}{c}0.191 \\
(0.023)\end{array}$ & $\begin{array}{c}0.061 \\
(0.033)\end{array}$ \\
\hline \multirow[t]{2}{*}{ Pell grant amount } & 1,272 & 785 & 2,480 & $\begin{array}{l}583 \\
(78)\end{array}$ & $\begin{array}{c}264 \\
(105)\end{array}$ \\
\hline & \multicolumn{5}{|c|}{ Financial Aid through 2009} \\
\hline Cumulative Pell grant & 2,961 & 2,127 & 3,780 & $\begin{array}{c}41 \\
(220)\end{array}$ & $\begin{array}{l}-734 \\
(265)\end{array}$ \\
\hline Cumulative Title IV borrowing & 5,019 & 2,033 & 4,599 & $\begin{array}{l}1702 \\
(331)\end{array}$ & $\begin{array}{l}1119 \\
(404)\end{array}$ \\
\hline Title IV loan balance, 2009 & 4,471 & 1,884 & 3,975 & $\begin{array}{l}1326 \\
(349)\end{array}$ & $\begin{array}{c}847 \\
(418)\end{array}$ \\
\hline $\begin{array}{l}\text { Repaid any amount on loan, } \\
\text { conditional on a student loan }\end{array}$ & 0.593 & 0.622 & 0.604 & $\begin{array}{l}-0.019 \\
(0.063)\end{array}$ & $\begin{array}{c}0.134 \\
(0.090)\end{array}$ \\
\hline $\begin{array}{l}\text { Defaulted on loan, } \\
\text { conditional on a student loan }\end{array}$ & 0.073 & 0.113 & 0.234 & $\begin{array}{c}0.084 \\
(0.045)\end{array}$ & $\begin{array}{c}0.098 \\
(0.037)\end{array}$ \\
\hline Left school in 2003-2004 & 0.240 & $\begin{array}{c}\text { Persistence a } \\
0.355\end{array}$ & $\begin{array}{l}\text { d Educationa } \\
\quad 0.288\end{array}$ & $\begin{array}{c}\text { Attainmer } \\
-0.020 \\
(0.032)\end{array}$ & $\begin{array}{l}-0.071 \\
(0.032)\end{array}$ \\
\hline Attained certificate & 0.227 & 0.424 & 0.537 & $\begin{array}{c}0.086 \\
(0.036)\end{array}$ & $\begin{array}{c}0.046 \\
(0.034)\end{array}$ \\
\hline Attained AA & 0.296 & 0.076 & 0.017 & $\begin{array}{l}-0.085 \\
(0.017)\end{array}$ & $\begin{array}{l}-0.065 \\
(0.019)\end{array}$ \\
\hline Still enrolled in 2009 & 0.319 & 0.261 & 0.206 & $\begin{array}{l}-0.035 \\
(0.031)\end{array}$ & $\begin{array}{l}-0.079 \\
(0.029)\end{array}$ \\
\hline Idle (not employed, not enrolled) & 0.178 & 0.166 & 0.269 & $\begin{array}{c}0.064 \\
(0.030)\end{array}$ & $\begin{array}{c}0.051 \\
(0.029)\end{array}$ \\
\hline Left survey & 0.040 & 0.067 & 0.040 & $\begin{array}{l}-0.022 \\
(0.014)\end{array}$ & $\begin{array}{l}-0.026 \\
(0.015)\end{array}$ \\
\hline
\end{tabular}




\begin{tabular}{|c|c|c|c|c|c|}
\hline Any job in 2009 & 0.711 & 0.779 & 0.669 & $\begin{array}{l}-0.065 \\
(0.036)\end{array}$ & $\begin{array}{l}-0.100 \\
(0.033)\end{array}$ \\
\hline Earnings from work in 2009 & 22,652 & 24,138 & 17,471 & $\begin{array}{l}-3,041 \\
(1490)\end{array}$ & $\begin{array}{l}-3,584 \\
(1422)\end{array}$ \\
\hline $\begin{array}{l}\text { Earnings from work in 2009, } \\
\text { conditional on employment }\end{array}$ & 31,873 & 30,967 & 26,119 & $\begin{array}{l}-1,576 \\
(1414)\end{array}$ & $\begin{array}{l}-2,473 \\
(1520)\end{array}$ \\
\hline Unemployed and seeking work & 0.250 & 0.144 & 0.256 & $\begin{array}{c}0.055 \\
(0.033)\end{array}$ & $\begin{array}{c}0.121 \\
(0.032)\end{array}$ \\
\hline $\begin{array}{l}\text { Unemployed more than } 3 \text { months } \\
\text { since leaving school }\end{array}$ & 0.415 & 0.271 & 0.439 & $\begin{array}{c}0.079 \\
(0.039)\end{array}$ & $\begin{array}{c}0.086 \\
(0.038)\end{array}$ \\
\hline $\begin{array}{l}\text { Earnings do not meet the } \\
\text { Gainful Employment standard }\end{array}$ & 0.092 & 0.031 & 0.229 & $\begin{array}{c}0.130 \\
(0.025)\end{array}$ & $\begin{array}{c}0.146 \\
(0.023)\end{array}$ \\
\hline Remedial coursework & 0.206 & $\begin{array}{l}\text { faction } n \\
0.244\end{array}$ & $\begin{array}{c}\text { ogram, } \\
0.049\end{array}$ & $\begin{array}{c}\text { l, Loans, } \\
-0.198 \\
(0.026)\end{array}$ & $\begin{array}{l}-0.199 \\
(0.027)\end{array}$ \\
\hline $\begin{array}{l}\text { Left school because dissatisfied, } \\
\text { 2003-2004 }\end{array}$ & 0.060 & 0.033 & 0.100 & $\begin{array}{c}0.065 \\
(0.018)\end{array}$ & $\begin{array}{c}0.064 \\
(0.013)\end{array}$ \\
\hline $\begin{array}{l}\text { Left school because dissatisfied, } \\
\text { 2003-2006 }\end{array}$ & 0.084 & 0.067 & 0.122 & $\begin{array}{c}0.060 \\
(0.023)\end{array}$ & $\begin{array}{r}0.066 \\
(0.015)\end{array}$ \\
\hline Education was worth the cost & 0.798 & 0.878 & 0.712 & $\begin{array}{l}-0.230 \\
(0.030)\end{array}$ & $\begin{array}{l}-0.221 \\
(0.028)\end{array}$ \\
\hline $\begin{array}{l}\text { Loans were a worthwhile } \\
\text { Investment }\end{array}$ & 0.823 & 0.806 & 0.680 & $\begin{array}{l}-0.109 \\
(0.038)\end{array}$ & $\begin{array}{l}-0.192 \\
(0.040)\end{array}$ \\
\hline $\begin{array}{l}\text { Satisfied with major } \\
\text { or course of study }\end{array}$ & 0.870 & 0.913 & 0.823 & $\begin{array}{l}-0.074 \\
(0.022)\end{array}$ & $\begin{array}{l}-0.063 \\
(0.023)\end{array}$ \\
\hline $\begin{array}{l}\text { Satisfied with current job } \\
\text { (employed, not enrolled) }\end{array}$ & 0.691 & 0.816 & 0.777 & $\begin{array}{l}-0.013 \\
(0.042)\end{array}$ & $\begin{array}{l}-0.083 \\
(0.035)\end{array}$ \\
\hline Sample size & 230 & 890 & 1,130 & & \\
\hline
\end{tabular}

Source: BPS:04/09 Restricted-Use Data File.

Notes: The regression sample only includes BPS students originally enrolled in a certificate program. The OLS column reports coefficient estimates (robust standard errors) for a for-profit institution dummy variable in regressions for each dependent variable that include the same additional covariates as those listed in the notes to Table 3. Each number in the Matching column represents the average treatment on the treated estimate (standard error) for going to a for-profit institution using from nearest neighbor (propensity score) matching with replacement and excluding observations outside of common support. The same covariates used in the OLS regressions were used for the matching models. The OLS and Matching model estimates use the BPS sampling weights. Unweighted sample sizes are rounded to the nearest 10 . 
Appendix Table 4: For-Profit Institution Impact on Student Outcomes for First-Time Undergraduates in Associate’s Programs: BPS:04/09

\begin{tabular}{|c|c|c|c|c|c|}
\hline \multirow[b]{3}{*}{ Dependent Variables } & \multicolumn{5}{|c|}{ Beginning Postsecondary Students, Associate’s Program Enrollees } \\
\hline & \multicolumn{3}{|c|}{ Dependent Variable Means } & \multicolumn{2}{|c|}{$\begin{array}{c}\text { For-Profit Institution } \\
\text { Impact }\end{array}$} \\
\hline & $\begin{array}{c}\text { (1) } \\
\text { Four-Year } \\
\text { Public and } \\
\text { Non-profits }\end{array}$ & $\begin{array}{c}\text { (2) } \\
\text { Two-Year } \\
\text { Public and } \\
\text { Non-profits }\end{array}$ & $\begin{array}{c}\text { (3) } \\
\text { For- profits }\end{array}$ & $\begin{array}{c}(4) \\
\text { OLS }\end{array}$ & $\begin{array}{c}\text { (5) } \\
\text { Matching }\end{array}$ \\
\hline & \multicolumn{5}{|c|}{ Financial Aid, 2003-2004 } \\
\hline Applied for Aid & 0.911 & 0.770 & 0.983 & $\begin{array}{c}0.108 \\
(0.015)\end{array}$ & $\begin{array}{c}0.077 \\
(0.015)\end{array}$ \\
\hline Title IV loan and grant aid & 4,372 & 1,031 & 7,296 & $\begin{array}{l}5,089 \\
(247)\end{array}$ & $\begin{array}{l}4,423 \\
(254)\end{array}$ \\
\hline Tuition & 6,883 & 1,301 & 8,500 & $\begin{array}{l}6,301 \\
(254)\end{array}$ & $\begin{array}{l}5,693 \\
(281)\end{array}$ \\
\hline Net tuition minus grants & 3,829 & 745 & 5,798 & $\begin{array}{l}4,885 \\
(234)\end{array}$ & $\begin{array}{l}4,795 \\
(247)\end{array}$ \\
\hline Pell grant & 0.433 & 0.311 & 0.717 & $\begin{array}{c}0.188 \\
(0.022)\end{array}$ & $\begin{array}{c}0.072 \\
(0.031)\end{array}$ \\
\hline \multirow[t]{2}{*}{ Pell grant amount } & 1,101 & 664 & 1,862 & $\begin{array}{l}494 \\
(72)\end{array}$ & $\begin{array}{c}110 \\
(103)\end{array}$ \\
\hline & \multicolumn{5}{|c|}{ Financial Aid through 2009} \\
\hline Cumulative Pell grant & 3,440 & 2,615 & 4,537 & $\begin{array}{c}125 \\
(201)\end{array}$ & $\begin{array}{l}-318 \\
(331)\end{array}$ \\
\hline Cumulative Title IV borrowing & 8,145 & 3,683 & 10,657 & $\begin{array}{l}5,891 \\
(639)\end{array}$ & $\begin{array}{l}5,214 \\
(558)\end{array}$ \\
\hline Title IV loan balance, 2009 & 7,854 & 3,467 & 10,888 & $\begin{array}{l}6,309 \\
(675)\end{array}$ & $\begin{array}{l}5,615 \\
(612)\end{array}$ \\
\hline $\begin{array}{l}\text { Repaid any amount on loan, } \\
\text { conditional on a student loan }\end{array}$ & 0.547 & 0.644 & 0.432 & $\begin{array}{l}-0.142 \\
(0.039)\end{array}$ & $\begin{array}{l}-0.080 \\
(0.044)\end{array}$ \\
\hline $\begin{array}{l}\text { Defaulted on loan, } \\
\text { conditional on a student loan }\end{array}$ & 0.074 & 0.052 & 0.152 & $\begin{array}{c}0.073 \\
(0.022)\end{array}$ & $\begin{array}{c}0.053 \\
(0.022)\end{array}$ \\
\hline Left school in 2003-2004 & 0.138 & $\begin{array}{c}\text { Persistence a } \\
0.217\end{array}$ & $\begin{array}{l}\text { Id Educationa } \\
0.121\end{array}$ & $\begin{array}{l}\text { Attainmen } \\
-0.083 \\
(0.020)\end{array}$ & $\begin{array}{l}-0.095 \\
(0.024)\end{array}$ \\
\hline Attained AA & & 0.224 & 0.284 & $\begin{array}{c}0.041 \\
(0.028)\end{array}$ & $\begin{array}{c}0.019 \\
(0.029)\end{array}$ \\
\hline Attained AA or more & & 0.283 & 0.291 & $\begin{array}{l}-0.006 \\
(0.028)\end{array}$ & $\begin{array}{l}-0.016 \\
(0.030)\end{array}$ \\
\hline Attained BA & 0.238 & 0.106 & 0.034 & $\begin{array}{l}-0.073 \\
(0.014)\end{array}$ & $\begin{array}{l}-0.068 \\
(0.017)\end{array}$ \\
\hline Still enrolled in 2009 & 0.238 & 0.106 & 0.034 & $\begin{array}{l}-0.073 \\
(0.014)\end{array}$ & $\begin{array}{l}-0.068 \\
(0.017)\end{array}$ \\
\hline Idle (not employed, not enrolled) & 0.138 & 0.122 & 0.199 & $\begin{array}{c}0.037 \\
(0.025)\end{array}$ & $\begin{array}{c}0.046 \\
(0.025)\end{array}$ \\
\hline Left survey & 0.351 & 0.400 & 0.234 & $\begin{array}{l}-0.145 \\
(0.028)\end{array}$ & $\begin{array}{l}-0.110 \\
(0.030)\end{array}$ \\
\hline
\end{tabular}




\begin{tabular}{|c|c|c|c|c|c|}
\hline Any job in 2009 & 0.789 & 0.797 & 0.749 & $\begin{array}{c}0.002 \\
(0.032)\end{array}$ & $\begin{array}{l}-0.043 \\
(0.031)\end{array}$ \\
\hline Earnings from work in 2009 & 25,867 & 25,232 & 21,413 & $\begin{array}{l}-1,880 \\
(1449)\end{array}$ & $\begin{array}{l}-552 \\
(1423)\end{array}$ \\
\hline $\begin{array}{l}\text { Earnings from work in 2009, } \\
\text { conditional on employment }\end{array}$ & 32,786 & 31,673 & 28,593 & $\begin{array}{l}-2,794 \\
(1476)\end{array}$ & $\begin{array}{c}-542 \\
(1657)\end{array}$ \\
\hline Unemployed and seeking work & 0.162 & 0.136 & 0.205 & $\begin{array}{c}0.035 \\
(0.029)\end{array}$ & $\begin{array}{c}0.087 \\
(0.029)\end{array}$ \\
\hline $\begin{array}{l}\text { Unemployed more than } 3 \text { months } \\
\text { since leaving school }\end{array}$ & 0.270 & 0.260 & 0.373 & $\begin{array}{c}0.084 \\
(0.035)\end{array}$ & $\begin{array}{c}0.045 \\
(0.036)\end{array}$ \\
\hline $\begin{array}{l}\text { Earnings do not meet the } \\
\text { Gainful Employment standard }\end{array}$ & 0.187 & 0.050 & 0.340 & $\begin{array}{c}0.256 \\
(0.031)\end{array}$ & $\begin{array}{c}0.176 \\
(0.030)\end{array}$ \\
\hline & \multicolumn{5}{|c|}{ Satisfaction with Program, School, Loans, Job } \\
\hline Remedial coursework & 0.248 & 0.307 & 0.106 & $\begin{array}{l}-0.178 \\
(0.022)\end{array}$ & $\begin{array}{l}-0.191 \\
(0.026)\end{array}$ \\
\hline $\begin{array}{l}\text { Left school because dissatisfied, } \\
\text { 2003-2004 }\end{array}$ & 0.039 & 0.022 & 0.058 & $\begin{array}{c}0.023 \\
(0.012)\end{array}$ & $\begin{array}{c}0.016 \\
(0.013)\end{array}$ \\
\hline $\begin{array}{l}\text { Left school because dissatisfied, } \\
\text { 2003-2006 }\end{array}$ & 0.074 & 0.049 & 0.108 & $\begin{array}{c}0.045 \\
(0.019)\end{array}$ & $\begin{array}{c}0.053 \\
(0.017)\end{array}$ \\
\hline Education was worth the cost & 0.789 & 0.807 & 0.571 & $\begin{array}{l}-0.230 \\
(0.030)\end{array}$ & $\begin{array}{l}-0.221 \\
(0.028)\end{array}$ \\
\hline $\begin{array}{l}\text { Loans were a worthwhile } \\
\text { Investment }\end{array}$ & 0.810 & 0.792 & 0.641 & $\begin{array}{l}-0.155 \\
(0.031)\end{array}$ & $\begin{array}{l}-0.079 \\
(0.031)\end{array}$ \\
\hline $\begin{array}{l}\text { Satisfied with major } \\
\text { or course of study }\end{array}$ & 0.849 & 0.859 & 0.742 & $\begin{array}{l}-0.120 \\
(0.028)\end{array}$ & $\begin{array}{l}-0.088 \\
(0.025)\end{array}$ \\
\hline $\begin{array}{l}\text { Satisfied with current job } \\
\text { (employed, not enrolled) }\end{array}$ & 0.794 & 0.751 & 0.704 & $\begin{array}{l}-0.033 \\
(0.040)\end{array}$ & $\begin{array}{l}-0.030 \\
(0.037)\end{array}$ \\
\hline Sample size & 870 & 3,720 & 570 & & \\
\hline
\end{tabular}

Source: BPS:04/09 Restricted-Use Data File.

Notes: The regression sample only includes BPS students originally enrolled in an associate's degree program. The OLS column reports coefficient estimates (robust standard errors) for a for-profit institution dummy variable in regressions for each dependent variable that include the same additional covariates as those listed in the notes to Table 3. Each number in the Matching column represents the average treatment on the treated estimate (standard error) for going to a for-profit institution using from nearest neighbor (propensity score) matching with replacement and excluding observations outside of common support. The same covariates used in the OLS regressions were used for the matching models. The OLS and Matching model estimates use the BPS sampling weights. Unweighted sample sizes are rounded to the nearest 10 . 
Appendix Table 5: For-Profit Institution Impact on Student Outcomes for First-Time Undergraduates in Bachelor's Programs: BPS:04/09

\begin{tabular}{|c|c|c|c|c|c|}
\hline \multirow[b]{3}{*}{ Dependent Variables } & \multicolumn{5}{|c|}{ Beginning Postsecondary Students, Bachelor's Program Enrollees } \\
\hline & \multicolumn{3}{|c|}{ Dependent Variable Means } & \multicolumn{2}{|c|}{$\begin{array}{c}\text { For-Profit Institution } \\
\text { Impact }\end{array}$} \\
\hline & $\begin{array}{c}\text { (1) } \\
\text { Four-Year } \\
\text { Public and } \\
\text { Non-profits }\end{array}$ & $\begin{array}{c}\text { (2) } \\
\text { Two-Year } \\
\text { Public and } \\
\text { Non-profits }\end{array}$ & $\begin{array}{c}\text { (3) } \\
\text { For- profits }\end{array}$ & $\begin{array}{c}(4) \\
\text { OLS }\end{array}$ & $\begin{array}{c}\text { (5) } \\
\text { Matching }\end{array}$ \\
\hline & \multicolumn{5}{|c|}{ Financial Aid, 2003-2004 } \\
\hline Applied for Aid & 0.897 & 0.754 & 0.989 & $\begin{array}{c}0.123 \\
(0.019)\end{array}$ & $\begin{array}{c}0.111 \\
(0.028)\end{array}$ \\
\hline Title IV loan and grant aid & 3,837 & 1,227 & 8,518 & $\begin{array}{l}5,199 \\
(692)\end{array}$ & $\begin{array}{l}3,505 \\
(641)\end{array}$ \\
\hline Tuition & 9,680 & 1,494 & 10,060 & $\begin{array}{l}5,084 \\
(475)\end{array}$ & $\begin{array}{l}2,205 \\
(795)\end{array}$ \\
\hline Net tuition minus grants & 5,415 & 918 & 6,741 & $\begin{array}{l}4,464 \\
(520)\end{array}$ & $\begin{array}{l}3,498 \\
(600)\end{array}$ \\
\hline Pell grant & 0.268 & 0.274 & 0.564 & $\begin{array}{c}0.112 \\
(0.031)\end{array}$ & $\begin{array}{l}-0.028 \\
(0.056)\end{array}$ \\
\hline \multirow[t]{2}{*}{ Pell grant amount } & 733 & 631 & 1535 & $\begin{array}{l}319 \\
(111)\end{array}$ & $\begin{array}{l}-173 \\
(176)\end{array}$ \\
\hline & \multicolumn{5}{|c|}{ Financial Aid through 2009} \\
\hline Cumulative Pell grant & 2,903 & 2,398 & 4,257 & $\begin{array}{l}-358 \\
(412)\end{array}$ & $\begin{array}{l}-1,067 \\
(608)\end{array}$ \\
\hline Cumulative Title IV borrowing & 8,993 & 4,483 & 13,750 & $\begin{array}{l}4,744 \\
(1262)\end{array}$ & $\begin{array}{l}3,222 \\
(1383)\end{array}$ \\
\hline Title IV loan balance, 2009 & 8,273 & 4,284 & 13,924 & $\begin{array}{l}5,240 \\
(1392)\end{array}$ & $\begin{array}{l}3,439 \\
(1503)\end{array}$ \\
\hline $\begin{array}{l}\text { Repaid any amount on loan, } \\
\text { conditional on a student loan }\end{array}$ & 0.652 & 0.638 & 0.476 & $\begin{array}{l}-0.138 \\
(0.062)\end{array}$ & $\begin{array}{l}-0.189 \\
(0.075)\end{array}$ \\
\hline $\begin{array}{l}\text { Defaulted on loan, } \\
\text { conditional on a student loan }\end{array}$ & 0.029 & 0.058 & 0.092 & $\begin{array}{l}0.020 \\
(0.036)\end{array}$ & $\begin{array}{l}-0.013 \\
(0.034)\end{array}$ \\
\hline Left school in 2003-2004 & 0.043 & $\begin{array}{c}\text { Persistence a } \\
0.151\end{array}$ & $\begin{array}{l}\text { Id Educationa } \\
0.108\end{array}$ & $\begin{array}{l}\text { Attainmen } \\
-0.020 \\
(0.032)\end{array}$ & $\begin{array}{l}-0.028 \\
(0.036)\end{array}$ \\
\hline Attained BA & 0.658 & 0.203 & 0.262 & $\begin{array}{l}-0.115 \\
(0.045)\end{array}$ & $\begin{array}{l}-0.194 \\
(0.052)\end{array}$ \\
\hline Still enrolled in 2009 & 0.257 & 0.409 & 0.222 & $\begin{array}{l}-0.142 \\
(0.041)\end{array}$ & $\begin{array}{l}-0.022 \\
(0.050)\end{array}$ \\
\hline Idle (not employed, not enrolled) & 0.099 & 0.112 & 0.199 & $\begin{array}{c}0.088 \\
(0.039)\end{array}$ & $\begin{array}{c}0.072 \\
(0.045)\end{array}$ \\
\hline Left survey & 0.109 & 0.146 & 0.116 & $\begin{array}{l}-0.016 \\
(0.034)\end{array}$ & $\begin{array}{l}-0.028 \\
(0.038)\end{array}$ \\
\hline Any job in 2009 & $\begin{array}{l}\text { Employm } \\
0.852\end{array}$ & $\begin{array}{l}\text { ent and Earnin } \\
0.821\end{array}$ & $\begin{array}{l}0.749 \\
\text { ss (conditiona }\end{array}$ & $\begin{array}{l}\text { no long } \\
-0.078 \\
(0.046)\end{array}$ & $\begin{array}{l}\text { nrolled) } \\
-0.069 \\
(0.055)\end{array}$ \\
\hline
\end{tabular}




\begin{tabular}{|c|c|c|c|c|c|}
\hline Earnings from work in 2009 & 29,434 & 25,130 & 28,159 & $\begin{array}{c}500 \\
(2629)\end{array}$ & $\begin{array}{l}-1,065 \\
(2723)\end{array}$ \\
\hline $\begin{array}{l}\text { Earnings from work in 2009, } \\
\text { conditional on employment }\end{array}$ & 34,528 & 30,617 & 37,578 & $\begin{array}{c}3,471 \\
(2707)\end{array}$ & $\begin{array}{l}1,014 \\
(2685)\end{array}$ \\
\hline Unemployed and seeking work & 0.110 & 0.142 & 0.223 & $\begin{array}{c}0.091 \\
(0.044)\end{array}$ & $\begin{array}{r}0.136 \\
(0.049)\end{array}$ \\
\hline $\begin{array}{l}\text { Unemployed more than } 3 \text { months } \\
\text { since leaving school }\end{array}$ & 0.227 & 0.255 & 0.353 & $\begin{array}{c}0.098 \\
(0.052)\end{array}$ & $\begin{array}{c}0.047 \\
(0.051)\end{array}$ \\
\hline $\begin{array}{l}\text { Earnings do not meet the } \\
\text { Gainful Employment standard }\end{array}$ & 0.131 & 0.060 & 0.298 & $\begin{array}{l}0.157 \\
(0.051)\end{array}$ & $\begin{array}{c}0.183 \\
(0.055)\end{array}$ \\
\hline & \multicolumn{5}{|c|}{ Satisfaction with Program, School, Loans, Job } \\
\hline Remedial coursework & 0.167 & 0.295 & 0.122 & $\begin{array}{l}-0.098 \\
(0.033)\end{array}$ & $\begin{array}{l}-0.128 \\
(0.043)\end{array}$ \\
\hline $\begin{array}{l}\text { Left school because dissatisfied, } \\
\text { 2003-2004 }\end{array}$ & 0.007 & 0.020 & 0.046 & $\begin{array}{l}0.025 \\
(0.019)\end{array}$ & $\begin{array}{c}0.033 \\
(0.019)\end{array}$ \\
\hline $\begin{array}{l}\text { Left school because dissatisfied, } \\
\text { 2003-2006 }\end{array}$ & 0.026 & 0.038 & 0.101 & $\begin{array}{c}0.060 \\
(0.029)\end{array}$ & $\begin{array}{c}0.072 \\
(0.025)\end{array}$ \\
\hline Education was worth the cost & 0.806 & 0.799 & 0.581 & $\begin{array}{l}-0.207 \\
(0.048)\end{array}$ & $\begin{array}{l}-0.167 \\
(0.050)\end{array}$ \\
\hline $\begin{array}{l}\text { Loans were a worthwhile } \\
\text { Investment }\end{array}$ & 0.843 & 0.819 & 0.685 & $\begin{array}{l}-0.133 \\
(0.049)\end{array}$ & $\begin{array}{l}-0.058 \\
(0.053)\end{array}$ \\
\hline $\begin{array}{l}\text { Satisfied with major } \\
\text { or course of study }\end{array}$ & 0.862 & 0.898 & 0.776 & $\begin{array}{l}-0.089 \\
(0.045)\end{array}$ & $\begin{array}{l}-0.067 \\
(0.039)\end{array}$ \\
\hline $\begin{array}{l}\text { Satisfied with current job } \\
\text { (employed, not enrolled) }\end{array}$ & 0.776 & 0.772 & 0.787 & $\begin{array}{c}0.057 \\
(0.053)\end{array}$ & $\begin{array}{l}-0.011 \\
(0.069)\end{array}$ \\
\hline Sample size & 7,180 & 650 & 180 & & \\
\hline
\end{tabular}

Source: BPS:04/09 Restricted-Use Data File.

Notes: The regression sample only includes BPS students originally enrolled in a bachelor's degree program. The OLS column reports coefficient estimates (robust standard errors) for a for-profit institution dummy variable in regressions for each dependent variable that include the same additional covariates as those listed in the notes to Table 3. Each number in the Matching column represents the average treatment on the treated estimate (standard error) for going to a for-profit institution using from nearest neighbor (propensity score) matching with replacement and excluding observations outside of common support. The same covariates used in the OLS regressions were used for the matching models. The OLS and Matching model estimates use the BPS sampling weights. Unweighted sample sizes are rounded to the nearest 10 . 